\title{
Scents of Space: Early Islamic Pilgrimage, Perfume, and Paradise
}

\author{
Adam Bursi* \\ Utrecht University, Utrecht, Netherlands \\ adambursi@gmail.com
}

\begin{abstract}
Within some of the earliest textual and material evidence for the history of Islam, pilgrimage appears as an important ritual of devotion, identity, and community. Yet modern scholarship has given little attention to early Muslims' sensory experiences of pilgrimage sites and what they physically encountered while there. This article examines the importance of smell within Islamic pilgrimage practices of the first/seventh and second/eighth centuries. Drawing upon literary and material evidence, I reconstruct several olfactory components of pilgrimage in this period, including intensive usage of perfume and incense at pilgrimage destinations such as the Kaba and the Dome of the Rock, as well as pilgrims' collection and ingestion of scented materials from these locations. I then argue that the prominence of pleasing aromas at these sacred spaces is connecting to early Islamic ideas about the proximity of paradise to these pilgrimage sites.
\end{abstract}

\section{Keywords}

pilgrimage, ḩağğ, Dome of the Rock, Jerusalem, Mecca, smell, perfume, incense, paradise

* The research for this article was partially funded and carried out as part of the E RC Consolidator Grant project "The Senses of Islam: A Cultural History of Perception in the Muslim World" (project $\mathrm{n}^{\circ}$ 724951). Versions were presented to audiences at the 2017 American Academy of Religion Annual Meeting in Boston, the Silsila: Center for Material Histories at New York University, and the 2019 Indiana University Medieval Studies Symposium. I am especially grateful to Eyad Abuali, Arash Ghajarjazi, Kim Haines-Eitzen, Christian Lange, David Powers, and the anonymous reviewers for reading and commenting upon previous drafts, and Yael Wender for her generous last-minute help. All errors are my own. 


\section{Résumé}

Dans certaines des premières sources textuelles et matérielles de l'histoire de l'islam, le pèlerinage apparaît comme un rituel important de dévotion, d'identité et de communauté. Néanmoins, dans la recherche contemporaine, les expériences sensorielles sur les sites du pèlerinage des musulmans ont fait l'objet de peu d'études. Cet article examine l'importance de l'odorat dans les pratiques islamiques du pèlerinage des $\mathrm{I}^{\mathrm{er}} / \mathrm{VII}^{\mathrm{e}}$ et $\mathrm{II}^{\mathrm{e}} / \mathrm{VIII}^{\mathrm{e}}$ siècles. En m'appuyant sur des sources littéraires et matérielles, je reconstruis de nombreuses composantes de l'olfaction dans le pèlerinage à cette époque, y compris l'importante utilisation de parfums et d'encens dans les lieux de pèlerinage tels que la Ka'ba et le Dôme du Rocher, ainsi que la collecte et l'ingestion de matériaux parfumés par les pèlerins à partir de ces emplacements. Je soutiens ensuite que l'importance des aromates dans ces espaces sacrés est liée aux premières représentations islamiques sur la proximité du paradis avec ces sites de pèlerinage.

\section{Mots clefs}

pèlerinage, ḩağğ, Dôme du Rocher, Jérusalem, Mecque, odeur, parfum, encens, paradis

Within the study of early Islam, one of the most long-debated subjects has been the purpose and meaning of the Dome of the Rock, built on the Temple Mount in Jerusalem in the 7os/69os. ${ }^{1}$ Though much of this discussion has turned on interpretations of the Dome's architecture, iconography, and inscriptions, recent scholarship has incorporated an important additional feature of the building's early history: the extensive perfuming and incensing of the Foundation Stone (in Arabic, Sahra) and the interior of the building that was carried out to prepare the space for visitors. According to literary traditions likely dating from the late Umayyad period, ${ }^{2}$ the Dome's attendants twice-weekly covered

1 The bibliography on this topic is huge. For a recent contribution with a useful overview of previous scholarship, see Milka Levy-Rubin, "Why Was the Dome of the Rock Built? A New Perspective on a Long-Discussed Question," Bulletin of the School of Oriental and African Studies, 8o/3 (2017), p. 441-464.

2 On the dating of these traditions, see Meir Jacob Kister, "A Comment on the Antiquity of Traditions Praising Jerusalem," The Jerusalem Cathedra, 1 (1981), p. 185-186; Amikam Elad, Medieval Jerusalem and Islamic Worship: Holy Places, Ceremonies, Pilgrimage, Leiden-New York-Köln, E.J. Brill ("Islamic History and Civilization," 8), 1995, p. 17-22; id., "Why Did 'Abd al-Malik Build the Dome of the Rock? A Re-Examination of the Muslim Sources," in Bayt 
the entire Șahra in a perfume made from musk, ambergris, saffron, and other luxurious materials, before circumambulating the Stone with censers burning scented woods, filling the entire space with fragrant smoke. When these rituals were complete, the curtains were raised, allowing the smoke to billow out, and an announcement was made: "The Șahra is open for the people! Whosoever wants to pray [therein], let them come!" Visitors would rush to pray within the Sahra space, and often reeked so strongly afterwards that "one who smells of its scent, they say of him, "This is one of those who have entered the Șahra."”3

According to this description, visiting the Dome of the Rock was heavily infused with the experience of scent: nearly every spot within the building was invested with perfume and incense-from the Foundation Stone to the Dome's top-and these smells accompanied its visitors after they left, marking them as pilgrims to the sacred space. Yet scholars who have analyzed the ritual scenting of the Dome have paid scant attention to this highly sensorial experience for early Muslim pilgrims, focusing instead upon identifying connections between these rituals and earlier Jewish and Christian practices at or near the Temple Mount in Jerusalem, especially those that had been carried out at the ancient Israelite Temple. ${ }^{4}$ Some of these scholars have even marginalized the rich olfactory aspects of early Muslims' worship there as foreign to Islam,

al-Maqdis: 'Abd al-Malik's Jerusalem, eds Julian Raby and Jeremy Johns, Oxford-New York, Oxford University Press ("Oxford Studies in Islamic Art," 9), 1992, p. 39-40, 47-48; Suleiman Ali Mourad, "The Symbolism of Jerusalem in Early Islam," in Jerusalem: Idea and Reality, eds Tamar Mayer and Suleiman Ali Mourad, London-New York, Routledge ("Middle East Studies/Middle East Society"), 2008, p. 9o; Alain George, "Paradise or Empire? On a Paradox of Umayyad Art," in Power, Patronage, and Memory in Early Islam: Perspectives on Umayyad Elites, eds Alain George and Andrew Marsham, New York, Oxford University Press, 2018, p. 46.

3 Abū Bakr Muḥammad b. Aḥmad al-Wāsițī, Faḍā̉il al-bayt al-muqaddas, ed. Isaac Hasson, Jerusalem, Magness Press ("Max Schloessinger Memorial Series," 3), 1979, p. 82-83 (no 136); Abū l-Ma'ālī l-Mušarraf b. al-Muraǧğā b. Ibrāhīm al-Maqdisī, Faḍāil bayt al-maqdis wa-l-halīl wa-faḍāil al-Šām, ed. Ofer Livne-Kafri, Šafā 'Amr, Dār al-mašriq, 1995, p. 59-6o (nº 47); Sibṭ b. al-Ǧawzī, Mir'āt al-zamān, ed. and transl. in Elad, "Why Did 'Abd al-Malik," p. 36, 55; Šihāb al-Dīn Abū Maḥmūd b. Tamīm al-Maqdisī, Muțīr al-garām ilā ziyārat al-Quds wa-l-Šām, ed. Aḥmad al-Hुuțaymī, Beirut, Dār al-ğ̄il, 1994, p. 173; Muğīr al-Dīn al-Ḥanbalī l-Ulaymī, al-Uns al-ğalīl bi-ta'rīh al-Quds wa-l-halīl, ed. 'Adnān Yūnus 'Abd al-Mağīd Abū Tabbāna, Amman, Maktabat Dandīs, 1999, I, p. 403-404; Šams al-Dīn al-Suyūțī, Ithâa al-ahișșā bi-faḍāil al-masğid al-aqșā, ed. Aḥmad Ramaḍān Aḥmad, Cairo, al-Hay’a l-miṣriyya l-āmma li-l-kitāb, 1982-1984, I, p. 242-243.

4 Moshe Sharon, "The 'Praises of Jerusalem' as a Source for the Early History of Jerusalem," Bibliotheca Orientalis, 49/1-2 (1992), p. 58-63; Heribert Busse, "The Temple of Jerusalem and Its Restitution by 'Abd al-Malik b. Marwān," in The Real and Ideal Jerusalem in Jewish, Christian and Islamic Art: Studies in Honor of Bezalel Narkiss on the Occasion of his Seventieth Birthday, ed. Bianca Kühnel, Jerusalem, Hebrew University of Jerusalem, 1998, p. 23-33; Pamela Berger, 
as in comments that "there is nothing remotely Islamic in" 5 the scenting of the Dome, and that these practices were "abolished as the Islamization of the Haram proceeded." Rather than an aspect of veneration within an early Islamic sacred space, these scents have often been interpreted as an anomaly dependent upon the Dome's location on the Temple Mount and the specifically Jewish and Christian resonances of the space and the rituals carried out there.

These olfactory rituals at the Dome of the Rock likely did, in fact, parallel Jewish and Christian usages of perfume and incense, as well as those communities' beliefs regarding the connections between pleasant scent, divine presence, and sacred space. ${ }^{7}$ Yet such sensory practices were not as unusual among early Muslims as modern scholars have sometimes suggested or assumed, and were not restricted to the Dome of the Rock in Jerusalem. ${ }^{8}$ Sweet scents figured prominently at several other important early Islamic sacred spaces, including the Ka'ba in Mecca and the Prophet's Mosque in Medina. ${ }^{9}$ Like those who visited the Dome, pilgrims to these other locations navigated heavily perfumed

The Crescent on the Temple: the Dome of the Rock as Image of the Ancient Jewish Sanctuary, Leiden, Brill ("Studies in Religion and the Arts," 5), 2012, p. 48-5o; Stephen J. Shoemaker, The Death of a Prophet: The End of Muhammad's Life and the Beginnings of Islam, Philadelphia, University of Pennsylvania Press ("Divinations"), 2011, p. 234-236. A similar emphasis on "preIslamic antecedents" has historically characterized the study of hağğ rituals: Marion Katz, "The Hajj and the Study of Islamic Ritual," Studia Islamica, 98-99 (2004), p. 95.

5 Sharon, "The 'Praises of Jerusalem," p. 64-65. Similar comments appear in: id., "Shape of the Holy," Studia Orientalia Electronica, 107 (2009), p. 283-310.

6 Busse, "The Temple of Jerusalem," p. 33.

7 Nina Ergin, "The Fragrance of the Divine: Ottoman Incense Burners and Their Context," Art Bulletin, 96/1 (2014), p. 70-97; Anya H. King, Scent from the Garden: Musk and the Medieval Islamic World, Leiden-Boston, Brill ("Islamic History and Civilization," 140), 2017, p. 340.

8 Incense practices are assumed to be absent from early Islam in: S. Brent Plate, A History of Religion in 5 1/2 Objects: Bringing the Spiritual to Its Senses, Boston, Beacon Press, 2015, p. 79; Lawrence Nees, Perspectives on Early Islamic Art in Jerusalem, Leiden-Boston, Brill ("Arts and Archaeology of the Islamic World," 5), 2016, p. 140. The significance of scents within medieval Islamic sacred spaces is largely minimized in: Julie Bonnéric, "Réflexions sur l'usage des produits odoriférants dans les mosquées au Proche-Orient $\left(\mathrm{I}^{\mathrm{er}} / \mathrm{VII}^{\mathrm{e}}-\mathrm{VI}^{\mathrm{e}} / \mathrm{XII}{ }^{\mathrm{e}} \mathrm{s}\right.$.), Bulletin d'Études Orientales, 64 (2016) [Histoire et anthropologie des odeurs en terre d'Islam à l'époque médiévale, ed. Julie Bonnéric], p. 293-320; Jean-Charles Ducène, "Des parfums et des fumées : les parfums à brûler en Islam medieval," Bulletin d'Études Orientales, 64 (2016), p. 159-178. However, Bonnéric notes that, compared to later centuries, there is "un recours plus fréquent aux substances odorantes à la période umayyade" and that "les mentions de produits odoriférants concernent principalement la période de califes rāšidūn et la période umayyade": Bonnéric, "Réflexions sur l'usage," p. 299, 308.

9 As has been noted previously by: Julian Raby, "In Vitro Veritas: Glass Pilgrim Vessels from 7th-Century Jerusalem," in Bayt al-Maqdis: Jerusalem and Early Islam, ed. Jeremy Johns, Oxford-New York, Oxford University Press ("Oxford Studies in Islamic Art," 9/2), 1999, 
and incensed buildings and absorbed odiferous materials that they inadvertently (and sometimes purposefully) brought home with them. Rather than an anomaly dependent upon Jewish and Christian precedents in Jerusalem, the odors cultivated at the Dome of the Rock likely complemented those found throughout the emergent Islamic sacred landscape.

Though scholarship on early Islam has noted the role of pilgrimage to sites such as the Dome of the Rock for early Muslims' religio-political affiliations and identities, ${ }^{10}$ little research has focused on pilgrims' sensorial experiences of pilgrimage spaces or on the ways in which their embodied experiences may have reflected/affected their understandings of the nature and significance of the sacred spaces to which pilgrimage was made. ${ }^{11}$ In this essay, I argue that scent was an important aspect of Islamic pilgrimage spaces in the first/seventh and second/eighth centuries that was actively supported by early patrons and played a vital role in visitors' experiences of these locations. Drawing upon literary and material evidence, I reconstruct several olfactory aspects of Islamic pilgrimage of this period, including the prominent usage of perfume and incense at pilgrimage destinations, as well as the collection of scented materials from these locations. Returning, then, to the question of the "meaning" of the Dome of the Rock for early Muslims, I suggest that the olfactory rituals carried out there and at other early pilgrimage shrines reflect: (1) the strong connections between sweet scents and paradise found in early Islamic traditions and (2) early Islamic conceptions of pilgrimage spaces as paradisiacal

p. 177; Gülru Necıpoğlu, "The Dome of the Rock as Palimpsest: 'Abd al-Malik's Grand Narrative and Sultan Süleyman's Glosses," Muqarnas, 25 (2008), p. 40-41.

10 Gerald R. Hawting, "The Hajj in the Second Civil War," in Golden Roads: Migration, Pilgrimage and Travel in Mediaeval and Modern Islam, ed. Ian Richard Netton, Richmond, Curzon Press, 1993, p. 31-42; Andrew Marsham, Rituals of Islamic Monarchy: Accession and Succession in the First Muslim Empire, Edinburgh, Edinburgh University Press, 20o9, p. 91, 124-125, 189, 279; Chase F. Robinson, 'Abd al-Malik, Oxford, OneWorld ("Makers of the Muslim World"), 2005, p. 95-100; M.E. McMillan, The Meaning of Mecca: The Politics of Pilgrimage in Early Islam, London, Saqi, 2011; Harry Munt, The Holy City of Medina: Sacred Space in Early Islamic Arabia, New York, Cambridge University Press ("Cambridge Studies in Islamic Civilization"), 2014, p. 141-147, 186-19o; Najam Haider, The Origins of the Shĩa: Identity, Ritual, and Sacred Space in Eighth-Century Küfa, New York, Cambridge University Press ("Cambridge Studies in Islamic Civilization"), 2011, p. 243-247.

11 For interesting work on sensorial aspects of premodern Islamic pilgrimage practices, see: Avinoam Shalem, "The Four Faces of the Ka'ba in Mecca," in Synergies in Visual CultureBildkulturen im Dialog: Festschrift für Gerhard Wolf, eds Annette Hoffmann, Manuela de Giorgi, and Nicola Suthor, Munich, Wilhelm Fink, 2013, p. 139-153; Béatrice Caseau, "The Senses in Religion: Liturgy, Devotion, and Deprivation," in A Cultural History of the Senses in the Middle Ages, ed. Richard G. Newhauser, London, Bloomsbury, 2014, p. 89-110. 
and eschatologically charged sites. A visit to the Dome of the Rock-like a visit to other early Islamic pilgrimage destinations-provided a whiff of the experience of heaven on earth and took part in the emergent Islamic syllabary of sacred space and its sensory perception.

\section{The Politics of Perfume at Pilgrimage Sites}

Early textual sources contain traces of information indicating that pleasant scent was cultivated at Muslims' sacred spaces from the very inception of Islamic history. ${ }^{12}$ Hadit texts place the scenting of mosques, for example, among the first Muslims: the Prophet Muhammad authorizes his followers to (de)odorize their mosques with perfumes, ${ }^{13}$ and the caliph 'Umar b. al-Huattāa (r. 13/634-23/644) prescribes that a censer be used to incense the mosque in Medina on Fridays and during the month of Ramadān..$^{14}$ Such practices appear to have spread widely throughout the emergent Islamicate world: incense reportedly was burned in the mosque in Fustạaț in the mid-first/seventh century; ${ }^{15}$ the Küfan jurist Ibrāhīm al-Naḩa'ì (d. ca 96/714) "did not disapprove" when he saw that the mosque there was scented with halüq (a saffron-based perfume

12 On scent in early Islam generally and at sacred spaces specifically, see: Mary Thurlkill, Sacred Scents in Early Christianity and Islam, Lanham-Boulder-New York-London, Lexington Books ("Studies in Body and Religion"), 2016; Ergin, "The Fragrance of the Divine," p. 72-73.

13 Abū Bakr b. Abī Šayba, al-Mușannaf li-Bn Abī Šayba, ed. Abū Muḥammad Usāma b. Ibrāhīm b. Muhammad, Cairo, al-Fārūq al-ḥadīta, 2008, III, p. 310 (n ${ }^{\text {os }} 75^{20}$, 7521, 7523); 'Abd al-Razzāq b. Hammām al-Ṣanānī, al-Mușannaf, ed. Ḥabīb al-Raḥmān al-A'ẓamī, Beirut, al-Maktab al-islāmī ("Manšūrāt al-mağlis al-ilmī̄" 39/1), 1983, I, p. 430-433

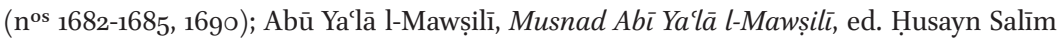
Asad, Damascus, Dār al-ma’mūn li-l-turāt, 1984-199o, viıI, p. 152 (nº 4698); 'Umar b. Šabba, Ta’rīh al-Madīna al-munawwwara, ed. Fahīm Muhammad Šaltūt, Beirut, Dār al-turāt, 199o, I, p. 18-28; 'Alī b. 'Abd Allāh al-Samhūdī, Wafā̄ al-wafā bi-ahbār Dār al-Mușțaāa, ed. Qāsim al-Sāmarrāì̄, London, Mu’assasat al-furqān li-l-turāt al-islāmī, 2001, II, p. 446-45o; III, p. 214; Raby, "In Vitro Veritas," p. 168, 177; Essam S. Ayyad, “The 'House of the Prophet' or the 'Mosque of the Prophet'?", Journal of Islamic Studies, 24/3 (2013), p. 291-292; Bonnéric, "Réflexions sur l'usage," p. 299-303.

14 Ibn Abī Šayba, al-Mușannaf, III, p. 310 (nº 7524); Abū Yálā, Musnad, I, p. 170 (nº 19o); Ibn Rusta, Kitāo al-Alāq al-nafìsa, ed. Michael Johan de Goeje, Leiden, Brill, 1892, p. 66; al-Samhūdī, Wafā' al-wafā, II, p. 45o; Ibn al-Nağğāār, al-Durra l-taminna fì ta'rīh al-Madīna, ed. Muḥammad Zaynahum Muḥammad 'Azab, Cairo, Maktabat al-țaqāfa l-dīniyya ("Turāt al-ğazīra l-'arabiyya"), 1995, p. 161-162.

15 Ibn 'Abd al-Ḥakam, Kitāb Futūḥ Miṣr wa-ahbāruhā, ed. Charles C. Torrey, New Haven, Yale University Press ("Yale Oriental Series. Researches," 3), 1922, p. 92. 
paste) $;{ }^{16}$ and two Bașran scholars-Tāābit b. Aslam al-Bunānī (d. ca 127/744) and Ḥumayd b. Mihrān al-Ṭawill (d. 142/759) — "would perfume themselves on the twenty-third and twenty-fourth days of Ramadān and approved of perfuming the mosque with scented water (nadūh)." ${ }^{\prime 17}$ The potent smell of some early mosques is apparent in the report that the jurist Makhūl al-Dimašqi (d. 110s/73os) "held his nose [...] to withdraw from the smell of the musk" produced by oil lamps burning within the monumental Umayyad Mosque in Damascus. ${ }^{18}$

While pleasant odors clearly left their impacts on early mosques, the locations that appear to have received the most sustained and expansive olfactory patronage in the first centuries after the Hiğra were the sacred places to which early Muslims made pilgrimage. Above, we saw the extensive aromatization carried out at the Dome of the Rock: these activities were possible thanks to the generous resources provided by the building's patron, the caliph 'Abd alMalik b. Marwān (r. 65/685-86/705), which included rooms within the complex for the manufacture of special perfumes, and a number of attendants (funded from the hums tax) tasked with carrying out the elaborate ritual of aromatizing the area surrounding the Rock..$^{19}$ At the Ka'ba in Mecca and the Prophet's Mosque in Medina, Muslim caliphs and governors-as patrons of these communal sacred spaces - similarly ensured that incense filled the interiors, and perfume coated the walls, of these great pilgrimage centers. Provisioning scent for these spaces was a duty of the Islamic political authorities that signaled their simultaneous veneration and control of these sites.

Competing historical claims regarding the origins of the Ka'ba's scents illustrate the religio-political connotations of providing scents for sacred spaces. While some sources indicate that scenting rituals were performed at the Ka'ba already in the pre-Islamic period, ${ }^{20}$ other traditions claim that the Ka ba began

16 Ibn Abī Šayba, al-Mușannaf, III, p. 310 (n $\left.{ }^{\mathrm{o}} 7525\right)$. On ḩalūq, see: Raby, "In Vitro Veritas," p. 172-177; King, Scent from the Garden, p. 281; Bonnéric, “Réflexions sur l'usage," p. 299-30o.

17 Ibn Abī l-Dunyā, Faḍ̂ảil ramaḍān, ed. 'Abd Allāh b. Ḥamad al-Manșūr, Riyadh, Dār alsalaf, 1995, p. 55 (n $\left.{ }^{\circ} 27\right)$.

18 Ibn 'Asākir, Ta'rīh madinnat Dimašq, ed. Muhịbb al-Dīn Abū Saīd 'Umar b. Garāma l-'Amrawī, Beirut, Dār al-fikr, 1995-2001, II, p. 278.

19 On these attendants and their role at the Dome, including the preparation of perfume, see: Elad, Medieval Jerusalem, p. 51-56; Raby, "In Vitro Veritas," p. 167-173; Andreas Kaplony, The Haram of Jerusalem 324-1099: Temple, Friday Mosque, Area of Spiritual Power, Stuttgart, Franz Steiner ("Freiburger Islamstudien," 22), 2002, p. 228, 324-326.

2o Abū l-Walīd Muḥammad b. 'Abd Allāh b. Aḥmad al-Azraqī, Ahbār Makka wa-mā ğăa fìhā min al-ātāâr, ed. 'Abd al-Malik b. 'Abd Allāh b. Duhayš, Mecca, Maktabat al-Asadī, 2003, p. 242, 354 ( ${ }^{\text {os }}$ 177, 280); 'Abd al-Malik b. Hišām, Kitāb Sirrat rasūl Allāh, ed. Ferdinand Wüstenfeld, Göttingen, Dieterichsche Universitäts-Buchhandlung, 1858-186o, 
to receive olfactory patronage only under the rule of the Umayyad caliph Mu'āwiya b. Abī Sufyān (r. 41/661-6o/68o), who was "the first to perfume the Kaba with halūq and incense,"21 and reportedly apportioned for the building a daily ration of perfume and dispatched incense and perfume for it during the hağğ season and during the sacred month of Rağab. ${ }^{22}$ However, other reports attribute such innovations in scenting the Ka'ba to 'Abd Allāh b. al-Zubayr, the "counter-caliph" who ruled the Hiğāa in opposition to the Umayyads between $60 / 68$ o and $73 / 692 .{ }^{23}$ Ibn al-Zubayr's challenge to Umayyad sovereignty rested in large part upon his control and patronage of the Kaba at Mecca: indeed, he called himself a "seeker of asylum at the House" ('âi $\underline{d}$ al-bayt) from Umayyad persecution. ${ }^{24}$ It is noteworthy, therefore, that-in direct opposition to these claims about Mu'āwiya - several traditions ascribe the institutionalization of the scenting of the building to Ibn al-Zubayr, saying that he was "the first to scent the building with perfume" (țīb, $\dot{g} \bar{a} l i y y a$, or halüq in different texts), ${ }^{25}$

I, p. 85; 'Abd al-Razzāq, al-Mușannaf, v, p. 86-87, 100 (nºs 9081, 9104); Abū Bakr Aḥmad b. al-Ḥusayn al-Bayhaqī, Dalāil al-nubuwwa wa-ma'rifat ahwwāl șāhib al-šarî́a, ed. 'Abd al-Mu'țī Amīn Qal'ağīi, Beirut, Dār al-kutub al-ilmiyya, 1988, II, p. 57; Robert Bertram Serjeant, South Arabian Hunt, London, Luzac, 1976, p. 61-62; Patricia Crone, Meccan Trade and the Rise of Islam, Princeton, Princeton University Press, 1987, p. 52, 75; Muhammad Abū l-Faḍl Ibrāhīm (ed.), Dīwān al-Nābig̉a l-Dַubyānī, Cairo, Dār al-macārif ("Dַhahāiir al'arab," 52), 199030, p. 25; Suzanne Pinckney Stetkevych, The Poetics of Islamic Legitimacy: Myth, Gender, and Ceremony in the Classical Arabic Ode, Bloomington, Indiana University Press, 2002, p. 23, 39. Some descriptions of Abraha's church, built in Yemen as a pilgrimage destination to rival the Ka'ba, mention the burning of aloeswood and the spreading of musk within it: Muhammad b. Sa'd, Kitāb al-Ṭabaqāt al-kabìr, ed. Eduard Sachau et al., Leiden, Brill, 1905-1940, I/I, p. 55; Abū Ğáfar Muhammad b. Ğarīr al-Ṭabarī, Ta’rīh al-rusul wa-l-mulūk: Annales quos scripsit Abu Djafar Mohammed ibn Djarir at-Tabari, ed. Michael Johan de Goeje et al., Leiden, Brill, 1879-19o1, I, p. 943.

Al-Azraqī, Ahbār Makka, p. $35^{8}$ (nº 291); Ibn al-Faqīh al-Hamadِānī, Kitāb al-Buldān, ed. Yūsuf al-Hādī, Beirut, 'Ālam al-kutub, 1996, p. 77; Yāqūt al-Ḥamawī, Mưğam al-buldān, Beirut, Dār Ṣādir, n.d., IV, p. 467; Bonnéric, “Réflexions sur l'usage," p. 303-304. Al-Azraqī, Ahbār Makka, p. 357 (nº 288).

23 Robinson, 'Abd al-Malik, p. 31-48.

24 Wilferd Madelung, "Abd Allāh b. al-Zubayr and the Mahdi," Journal of Near Eastern Studies, 40/4 (1981), p. 291-305; id., "Abd Allāh ibn al-Zubayr the mulhid," in Actas XVI Congreso UEAI, eds Concepción Vázquez de Benito and Miguel Ángel Manzano Rodríguez, Salamanca, Consejo superior de investigaciones científicas, 1995, p. 301-308; Mehdy Shaddel, "Abd Allāh ibn al-Zubayr and the Mahdī: Between Propaganda and Historical Memory in the Second Civil War," Bulletin of the School of Oriental and African Studies, 8o/1 (2017), p. 1-19.

25 Abū 'Abd Allāh Muḥammad b. Isḥāq b. al-'Abbās al-Fākihī, Ahbār Makka fì qadīm al-dahr wa-ḥadịtihi, ed. 'Abd al-Malik b. 'Abd Allāh b. Duhayš, Beirut, Dār Hị̣̂, 1994², III, p. 221 (nos 2008-2009); Ibn Wāḍị al-Ya'qūbī, Tảrīh, ed. Martijn T. Houtsma, Leiden, Brill, 1883, II, p. 311; Yāqūt, Mưğam al-buldān, IV, p. 467; Abū Hilāl al-Ḥasan b. 'Abd Allāh b. Sahl 
or that he was "the first to coat the interior (ğawf) of the Ka'ba with halūq."26 Both the Umayyad and the Zubayrid houses thus asserted their roles in establishing the ritual aromatization of the House at Mecca, and thereby in institutionalizing a component of the building's patronage in this early period.

Beyond claims to his being the "first" to do so, sources often more generally associate Ibn al-Zubayr's veneration and patronage of the Ka'ba with his care for the building's scents. He reportedly "would perfume the Ka'ba with a pound of incense every day, and two pounds on Fridays" 27 and (perhaps hyperbolically) "he perfumed the Ka'ba such that whoever entered the Haram encountered its scent," ${ }^{28}$ suggesting that the odor permeated the whole of Mecca's sacred territory. Such extensive perfuming activities likewise feature in many accounts of Ibn al-Zubayr's (in)famous reconstruction of the Ka'ba: in addition to the fine building materials commissioned for this project, reports also comment upon the aromatizing of the entirety of the Ka'ba during and/or after its construction, such as "when Ibn al-Zubayr finished building the Ka'ba, he perfumed it with halūq from inside and outside, from top to bottom" or "perfumed its interior with ambergris and musk and coated its exterior walls with musk."29 Given Ibn al-Zubayr's role in aggrandizing the Ka'ba, the prominent place of perfume and incense in his activities testifies to the significance of scent in early patronage of the building.

al-'Askarī, al-Awā̉il, ed. Muḥammad al-Sayyid al-Wakīl, Ṭanțā, Dār al-bašīr li-l-țaqāfa wa-l'ulūm al-islāmiyya, 1987, p. 55. On ga ăliya, a compound perfume containing musk and ambergris, see: King, Scent from the Garden, p. 278-28o, 284-29o; Amar Zohar and Efraim Lev, "Trends in the Use of Perfume and Incense in the Near East After the Muslim Conquests," Journal of the Royal Asiatic Society (Series 3), 23/1 (2013), p. 11-30.

26 Al-Azraqī, Ahbār Makka, p. 356, $362\left(\mathrm{n}^{\text {os }} 285,298\right)$.

27 Ibid., p. 362-363 (n ${ }^{\circ}$ 299).

28 Al-Zubayr b. Bakkār al-Qurašī l-Zubayrī, Ğamharat nasab Qurayš wa-ahbārihāa, ed. 'Abbās Hānī l-Ǧarrāh, Beirut, Dār al-kutub al-'ilmiyya, 2010, II, p. 272; Ibn 'Asākir, Ta’rīh madīnat Dimašq, XXVIII, p. 213; Šams al-Dīn al-Dahabī, Siyar a 'lām al-nubalā’, ed. Šu'ayb al-Arna’ūt et al., Beirut, Mu’assasat al-risāla, 1981-1988, III, p. 374.

29 Al-Azraqī, Ahbār Makka, p. 304-305, 312-313, 318 (n $\left.{ }^{\text {os }} 227,239,252\right)$; Ibn Abī Šayba, al-Muṣannaf, III, p. 310 (nº 7522); al-Ya'qūbī, Ta’rīhn, II, p. 311; Ibn Abī Zayd al-Qayrawānī, Kitāb al-Ǧāmi fí l-sunan wa-l-ādāb wa-l-mā ġāzī wa-l-ta'rịh, eds Muhammad Abū l-Ağfān and 'Uțmān al-Baț̣ị̂h, Beirut, Mu’assasat al-risāla ("Min turātinā l-islāmī," 17), 1983², p. 143; al-Nağm 'Umar b. Fahd, Ithăf al-warā bi-ahbār Umm al-Qurā, ed. Fahīm Muhamamad Šaltūt, Mecca, Ğāmi‘at Umm al-Qurā, 2005² II, p. 75; Quṭb al-Dīn Muhammad b. Aḥmad al-Nahrawālī, Kitāb al-Ilām bi-a lām bayt Allāh al-harām, ed. Ferdinand Wüstenfeld, Leipzig, F.A. Brockhaus ("Morgenländische Bibliothek"), 1857, p. 82. On Ibn al-Zubayr's building project, see: Gerald Hawting, "A Plaything for Kings': 'Ā'isha's Ḥadìth, Ibn alZubayr, and the Rebuilding of the Ka'ba," in Islamic Studies Today: Essays in Honor of Andrew Rippin, eds Majid Daneshgar and Walid A. Saleh, Leiden-Boston, Brill ("Texts and Studies on the Qurān," 11), 2016, p. 3-21. 
The symbolic power of the Ka'ba's scent is also suggested by its close association with another of the House's prized gifts, itself indicative of political authority and control: the building's kiswa, or covering. ${ }^{30}$ Several reports link patronage of the Ka'ba's kiswa with care for its perfumes. For example, during his reconstruction of the building, Ibn al-Zubayr placed under the care of the Ka'ba's attendants its ornaments, clothes, and perfume. ${ }^{31}$ The connection between these objects is more firmly indicated by the fact that the competing claims to precedence in scenting the Ka'ba are often directly connected with the similarly differing identifications of the first ruler to provide the House with a kiswa made of fine silk brocade (dība $\bar{a})$ ): here too, the claims of precedence for Umayyad rulers (including Mucāwiya and 'Abd al-Malik) appear directly in tension with those of Ibn al-Zubayr. ${ }^{32}$ This relationship between scent and kiswa is emphasized in the hagiographic report that "Abd Allāh [b. al-Zubayr] was the first to cover the Kaba with silk brocade, and he perfumed the Kaba such that whoever entered the Haram encountered its scent." ${ }^{33}$ After defeating Ibn al-Zubayr in 72/692 and (re)claiming the Hiğāz for Umayyad control, 'Abd al-Malik began his own program of patronage of the Kaba, sending perfume and incense alongside a silk kiswa for the building during each year of his rule. ${ }^{34}$ It thus appears that, like provisioning the Ka'ba's covering, patronizing

30 The provision of the kiswa was identified as a special "obligation and privilege" of the earliest caliphs: Maurice Gaudefroy-Demombynes, "Le voile de la Ka'ba," Studia Islamica, 2 (1954), p. 5-21; Richard T. Mortel, "The Kiswa: Its Origins and Development from Pre-Islamic Times until the End of the Mamlūk Period," al-'Ușūr/Ages, 3/2 (1988), p. 30-46.

$31 \quad$ Al-Ṭabarī, Ta'rīh, II, p. 537; al-Azraqī, Ahbār Makka, p. 315 (nº 244).

32 'Abd al-Razzāq, al-Mușannaf, v, p. 89 (nos 9085, 9087); al-Azraqī, Ahbār Makka, p. 356364 (n ${ }^{\text {os }} 285,288,290,292,301$ ); al-Fākihī, Ahbār Makka, III, p. 221 (nº 2008); al-Ya'qūbī, Ta’rịh, II, p. 311; Yāqūt, Mư̌ğam al-buldān, IV, p. 467; Abū Hilāl al-'Askarī, al-Awā̉il, p. 55; Ibn al-Faqīh, Kitāb al-Buldān, p. 77; Ibn Hišām, Sīra, I, p. 126; Muğ̄ir al-Dīn, al-Uns al-ğalīl, I, p. 406; Alexander Fodor, "The Pyramids in Arabic Folk Beliefs," in Occident and Orient: A Tribute to the Memory of Alexander Scheiber, ed. Robert Dán, Budapest-Leiden, Akadémiai Kiadó-E.J. Brill, 1988, p. 157; Mortel, “The Kiswa," p. 33-34.

33 Al-Zubayr b. Bakkār, Ğamharat nasab Quray̌s, II, p. 272; Ibn 'Asākir, Tảrīh madīnat Dimašq, XXVIII, p. 213; al-Dahabī, Siyar a lām al-nubalā', III, p. 374.

34 Al-Azraqī, Ahbār Makka, p. 359 (nº 294); Mortel, “The Kiswa," p. 34; Ghazi Izzeddin Bisheh, The Mosque of the Prophet at Madinah throughout the First-Century A.H. with Special Emphasis on the Umayyad Mosque, PhD thesis, University of Michigan, 1979, p. 247. He and his son al-Walīd are also said to have overseen renovations to the Ka'ba and the Meccan sanctuary, regarding which, see: Robinson, 'Abd al-Malik, p. 96-98; Gerald R. Hawting, "The Umayyads and the Hijāz," Proceedings of the Seminar for Arabian Studies, 2 (1972), p. 39-46; Fred M. Donner, "Umayyad Efforts at Legitimation: The Umayyads' Silent Heritage," in Umayyad Legacies: Medieval Memories from Syria to Spain, eds Antoine Borrut and Paul M. Cobb, Leiden-Boston, Brill (“Islamic History and Civilization," 80), 2010, p. 200-201. 
the building's scent was a caliphal prerogative and "one ingredient in the battle for religious legitimacy between the Zubayrids and the Marwanids." 35

With their defeat of the Umayyads in 132/749, the Abbasid dynasty took over control and support of the Kaba, including the aromatization of the building. ${ }^{36}$ A noteworthy example of the latter activity occurred during the rule of the caliph al-Mahdi (r. 158/775-169/785) when he led the hağğ in 160/777. Under al-Mahdi's orders, the Ka'ba was "anointed from inside and outside with $\dot{g} \bar{a}$ liya, musk, and ambergris, coating the whole of its exterior on all sides from top to bottom," and the building was then draped with several coverings (kusan), including one made of silk (hazz) and another of silk brocade. ${ }^{37}$ Another account—narrated by one of the Ka'ba's attendants, the hağabaexplains the mechanics of this process:

We climbed atop the rear of the Ka'ba with bottles of $\dot{g} \bar{a}$ liya and poured them out upon the Kaba's walls from every side. Servants of the Ka'ba had peeled up the Ka'ba's coverings with pulleys sewn onto [the coverings], and they painted its walls with the $\dot{g}$ alliya from top to bottom. ${ }^{38}$

Again the Ka'ba's kiswa and perfume are paired, here in an elaborate ceremony patronized by an early Abbasid caliph. Indeed, one report notes that "al-Mahdī sat on the side of the mosque [...] watching as [the Kacba] was painted with the $\dot{g} \bar{a} l i y a$ and draped with the kiswa." 39 Unlike the dueling Umayyad and Zubayrid claims to precedence in scenting the building, there is no indication here of Abbasid competition with other political regimes in their treatment of the Ka ba. Nonetheless, this perfuming was clearly a significant act of patronage for the space, carried out in the very presence of the caliph who, in this same period, paid for an extensive expansion and beautification of the Sacred Mosque (al-Masğid al-harām) around the Ka ${ }^{c} \mathrm{ba}^{40}$

35 Raby, "In Vitro Veritas," p. 183.

36 McMillan, The Meaning of Mecca, p. 158-16o; Travis Zadeh, "The Early Hajj: SeventhEighth Centuries CE," in The Hajj: Pilgrimage in Islam, eds Eric Tagliacozzo and Shawkat M. Toorawa, New York, Cambridge University Press, 2016, p. 42-64.

37 Al-Azraqī, Ahbār Makka, p. 368 (nº 311); al-Ya'qūbī, Ta’rīh, II, p. 476; al-Ṭabarī, Ta’rīh, III, p. 483; Muğīr al-Dīn, al-Uns al-ğalül, I, p. 407.

38 Al-Azraqī, Ahbār Makka, p. 367-368 ( $n^{\circ}$ 310). Parallel versions say that the servants "hung" or "suspended" (ta'callaqū) the coverings with pulleys: 'Umar b. Fahd, Ithäf al-warā, II, p. 204-205; al-Nahrawālī, al-I lām, p. 99. I thank the anonymous reviewers for drawing my attention to these parallel texts and for their assistance with this passage.

39 Al-Azraqī, Ahbār Makka, p. 368 (n $\left.{ }^{\circ} 311\right)$.

40 F.E. Peters, Mecca: A Literary History of the Muslim Holy Land, Princeton, Princeton University Press, 1994, p. 112-117; Robert Schick, "The Umayyads and 'Abbāsids in Mujīr 
Similar olfactory patronage also appeared at the Prophet's Mosque at Medina. As in the case of the Kacba, different figures are identified as the first to perfume the Prophet's Mosque: the Prophet Muhammad himself reportedly applied perfume to the mosque space, while the caliph 'Uțān b. 'Affān (r. 23/644-35/655) is credited as the "first to coat the mosque with halüq."41 Whatever the specific beginning of the practice, by the end of the first/seventh century, governors in Medina reportedly set aside resources from the public tithe for the "incensing of the Messenger of God's Mosque on Fridays and coating it with perfume during the month of Ramaḍān," much as the caliph "Umar had reportedly suggested should be done there. ${ }^{42}$

Over the course of the late first/seventh and second/eighth century, the mosque in Medina became an increasingly sanctified and visited space, with scent playing a part in this process. The Umayyads funded an extensive expansion and beautification of the building, a key component of which was the incorporation of the Prophet's tomb into the Mosque complex. ${ }^{43}$ Several Umayyad caliphs in this period sent special aromatic gifts for the Prophet's Mosque: 'Abd al-Malik reportedly dispatched, in addition to his gifts for the Kaba, perfume and incense for the Prophet's Mosque, where the kiswa was hung on the Mosque's columns for one day before being moved to the Ka'ba. ${ }^{44}$ Similarly, when he led the hağğ in 91/710, 'Abd al-Malik's son and caliphal successor al-Walìd (r. 86/705-96/715) personally delivered the Mosque's perfume and censer alongside the kiswa, which was again hung in the Mosque for one day before being transferred to Mecca. ${ }^{45}$ As they transformed Medina into a "holy city" and the Prophet's Mosque into a pilgrimage destination, these caliphs brought their patronage and authority to bear upon the Mosque, manifested in both the kiswa's presence there, and their gifts of scent for the space during the hağğ season. ${ }^{46}$

Patronage of scent at the Prophet's Mosque reached even grander heights later in the second/eighth century under the Abbasids. Historical sources describe a visit to the Prophet's Mosque during the hağğ of 170/787 by the Abbasid

al-Din's Fifteenth-Century History of Jerusalem and Hebron," in The Lineaments of Islam: Studies in Honor of Fred McGraw Donner, ed. Paul M. Cobb, Leiden, Brill ("Islamic History and Civilization," 95), 2012, p. 220; al-Ya'qūbī, Ta'rīh, II, p. 476-477. Ibn Šabba, Ta'rīh al-Madīna, III, p. 961; Ibn al-Nağǧār, al-Durra l-taminna, p. 162; al-Samhūdī, Wafă' al-wafā, II, p. 448. See the sources cited in note 13 above.

42 Ibn Sacd, al-Ṭabaqāt, v, p. 295.

43 Munt, The Holy City of Medina, p. 103-115.

44 Al-Azraqī, Ahbār Makka, p. 359 ( $\mathrm{n}^{\circ}$ 294); Bisheh, The Mosque of the Prophet at Madinah, p. 247; al-Samhūdī, Wafä̀ al-wafā, II, p. 350.

45 Al-Tabarī, Ta'rīh, II, p. 1234; Bisheh, The Mosque of the Prophet at Madinnah, p. 226-227.

46 Munt, The Holy City of Medina, p. 139, 164-165. 
queen al-Hayzurān, concubine of the caliph al-Mahdī (r. 158/775-169/785) and mother of the caliphs Mūsā l-Hādī (r. 169/785-170/786) and Hārūn al-Rašìd (r. 170/786-193/8o9). While there, al-Hayzurān commissioned for the mosque to be scented with halūq and placed her servant Mu'nisa in charge of carrying out her orders. ${ }^{47}$ Mu'nisa was then approached by Ibrāhīm b. al-Faḍl b. 'Ubayd Allāh b. Sulaymān, the mawlā of Hišām b. Ismācil al-Mahzūmī, who had served as the governor of Medina from 82/701 until 87/706 under the Umayyad caliphs 'Abd al-Malik and al-Walīd. ${ }^{48}$ Ibrāhīm asked Mu'nisa, "Do you [pl.] want to surpass those who come after you, by doing what those who came before you did not?" Asked what he meant, Ibrāhīm responded, "Cover the whole tomb in halūq!" Mu'nisa followed Ibrāhīm's advice, covering the whole of the Prophet's tomb in halūq, as well as two important columns at the front of the mosque: the "repentance column" and the column remembered as the Prophet's place of prayer. ${ }^{49}$

This story exposes clearly the politics of perfume at early Islamic sacred spaces. Ibrāhim - a servant of the Umayyad governor of Medina during that dynasty's greatest patronage of the Prophet's Mosque-advises a servant of the Abbasid regime to go even further in perfuming this location than its previous patrons had done. ${ }^{50}$ Much like the competition between the Umayyad and Zubayrid houses, we see here an explicit wish to compete with a rival dynasty in providing grand olfactory patronage to a pilgrimage place: an act that will "surpass those who come after you, by doing what those who came before you did not." Like the extensive perfuming of the Dome of the Rock under 'Abd al-Malik, the olfactory care for the Ka'ba and for the Prophet's Mosque by the Zubayrid, Umayyad, and Abbasid regimes testifies to the significance of scent

47 Kitāb al-Manāsik wa-amākin țuruq al-ḥağğ wa-macālim al-ğazirra, ed. Ḥamad al-Ğāsir, Riyadh, Manšūrāt dār al-Yamāma li-l-bahṭ wa-l-tarğama wa-l-našr ("Nuṣūṣ wa-abhāṭ̂ ğug̉rāfiyya wa-tārīhiyya 'an Ǧazīrat al-'arab," 9), 1969, p. 372; al-Samhūdī, Wafă’al-wafā, II, p. 88, 349-351, 449; Ibn al-Nağğār, al-Durra l-țamina, p. 162.

48 McMillan, The Meaning of Mecca, p. 92, 102-104; Šams al-Dīn al-Sahāwī, al-Tuhfa l-lațîfa fi ta'rīh al-madīna l-šarīfa, ed. As'ad Ṭarābzūnī l-Ḥusaynī, Cairo, Maṭba'at dār našr al-țaqāfa, 1979-1980, I, p. 82 ( ${ }^{\circ}$ 97).

49 On these columns, see: Mattia Guidetti, In the Shadow of the Church: The Building of Mosques in Early Medieval Syria, Leiden-Boston, Brill ("Arts and Archaeology of the Islamic World," 8), 2017, p. 153; Bisheh, The Mosque of the Prophet at Madinah, p. 141-142. Ibn 'Abd Rabbihi's fourth/tenth-century description of the Prophet's Mosque mentions several spaces in the building, including part of the Prophet's tomb, as "rubbed over with perfume" (muhallaq bi-l-halūq): Ibn 'Abd Rabbihi, al-Iqd al-farìd, ed. 'Abd al-Mağīd al-Tarhīnī, Beirut, Dār al-kutub al-'ilmiyya, 1983, viI, p. 288-289.

$5^{\circ}$ On early Abbasid patronage of sites in Medina, see: Munt, The Holy City of Medina, p. 115$120,165^{-172 .}$ 
at these early sacred spaces. Indeed, the competition between these rulers regarding claims to precedence and magnanimity suggests that the provision of scent likely functioned as a symbol of patronage signaling both care for, and control of, these sites.

\section{Smelling and Collecting Scents in Sacred Spaces}

These reports suggest that the scents provided to early Islamic pilgrimage spaces were often lavish — particularly during holy days associated with pilgrimage - and thus were almost certainly a vital part of pilgrims' experiences of these spaces. ${ }^{51}$ As in other late antique Near Eastern traditions, pilgrimage was constituted of a variety of multisensory phenomena: Christian and Jewish pilgrims looked upon and touched holy people, places, and things; listened to the prayers, chants, and songs accompanying such rituals; and smelled and tasted the incense, perfume, and oil emanating from these sacred spaces. ${ }^{2}$ The same was largely true of early Islamic pilgrimages, including

51 The months of Ramaḍān and Rağab are presented in some traditions as distinctly efficacious times for the performance of non-hağğ pilgrimage ('umra). See: Ibn Abī Šayba, al-Mușannaf, v, p. 161-163, 214-215 ( $\mathrm{n}^{\text {os }}$ 13175-13183, 13485-13491); Meir Jacob Kister, "Rajab is the Month of God': A Study in the Persistence of an Early Tradition," Israel Oriental Studies, 1 (1971), p. 219-223. These months also appear within traditions as times that scents were dispatched to the Ka'ba or the mosque at Medina was scented.

52 Béatrice Caseau, "Christian Bodies: The Senses and Early Byzantine Christianity," in Desire and Denial in Byzantium, ed. Liz James, Aldershot, Ashgate Variorum ("Society for the Promotion of Byzantine Studies," 6), 1999, p. 101-109; ead., "Experiencing the Sacred," in Experiencing Byzantium, eds Claire Nesbitt and Mark P.C. Jackson, Farnham-Burlington, Ashgate ("Society for the Promotion of Byzantine Studies," 18), 2016, p. 59-78; Georgia Frank, The Memory of the Eyes: Pilgrims to Living Saints in Christian Late Antiquity, Berkeley-Los Angeles-London, University of California Press ("The Transformation of the Classical Heritage," 30), 2000; Susan Ashbrook Harvey, Scenting Salvation: Ancient Christianity and the Olfactory Imagination, Berkeley-Los Angeles-London, University of California Press ("The Transformation of the Classical Heritage," 42), 2006, p. 89-90; ead., "Sensing More in Ancient Religion," Svensk Teologisk Kvartalskrift, 89 (2013), p. 97106; Liz James, "Senses and Sensibility in Byzantium," in Museum Objects: Experiencing the Properties of Things, ed. Sandra H. Dudley, London, Routledge ("Leicester Readers in Museum Studies"), 2012, p. 134-149; Paul A. Brazinski and Allegra R. P. Fryxell, "The Smell of Relics: Authenticating Saintly Bones and the Role of Scent in the Sensory Experience of Medieval Christian Veneration," Papers from the Institute of Archaeology, 23/1 (2013), p. 1-15; Heather Hunter-Crawley, "Movement as Sacred Mimesis at Abu Mena and Qal'at Sem'an," in Excavating Pilgrimage: Archaeological Approaches to Sacred Travel and Movement in the Ancient World, eds Troels Myrup Kristensen and Wiebke Friese, London, Routledge ("Routledge Studies in Pilgrimage, Religious Travel and Tourism"), 
those made to the great shrines of the Kaba, the Dome of the Rock, and the Prophet's Mosque. All of these locations offered visitors multisensory experiences of the holy through a variety of rituals, among which those involving scent were a key component, providing avenues through which early Muslims directly participated in the sacredness of these holy spaces.

The importance of scent is reflected, for example, in early reports that encourage the scenting of Islamic pilgrimage spaces as acts of piety and charity. ${ }^{53}$ As we have seen, Islamic authorities took great care in the provision of scent at pilgrimage centers, and official attendants were charged with carrying out these rituals. ${ }^{54}$ In addition, lay pilgrims (or would-be pilgrims) may have also participated in such olfactory tasks. According to a statement attributed to the Prophet's wife 'Â'iša, she commanded, "Perfume the Ka'ba! This is dearer to me than providing it with gold and silver." ${ }^{\prime 5}$ Here, 'A'iša indicates that the scenting of the Ka'ba is more important than its visual adornment. Similarly, when asked by a woman in Mecca whether or not she "should place a kiswa upon the Ka'ba," 'Á'iša advises, "The rulers will suffice you for that, but rather purify it with perfume." ${ }^{56}$ Here, a division of devotional labor is encouraged in which the "rulers" (al-umarä) are tasked with providing the kiswa, while individual visitors—including women — are charged with perfuming the building.

2017, p. 187-202; Joshua Levinson, "There Is No Place Like Home: Rabbinic Responses to the Christianization of Palestine," in Jews, Christians, and the Roman Empire: The Poetics of Power in Late Antiquity, ed. Natalie B. Dohrmann and Annette Yoshiko Reed, Philadelphia, University of Pennsylvania Press ("Jewish Culture and Contexts"), 2013, p. 99-120.

53 For similar late antique Christian practices: Caseau, "Christian Bodies," p. 108; Harvey, Scenting Salvation, p. 87; Gary Vikan, Early Byzantine Pilgrimage Art, Washington, Dumbarton Oaks ("Dumbarton Oaks Byzantine Collection Publications," 5), 2010², p. 51. On Jews and Christians providing perfume and oil for sites in early Islamic Jerusalem, see: Raby, "In Vitro Veritas," p. 176; Elad, Medieval Jerusalem, p. 64.

54 Like the attendants of the Dome of the Rock, the Ka'ba's attendants, the hağaba, perfumed and incensed the building as part of their care for the House: al-Fākihī, Ahbār

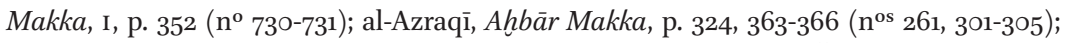
Ahbār al-dawla l-abbāsiyya, ed. 'Abd al-'Azīz al-Dūrī and 'Abd al-Ǧabbār al-Muțțalibī, Beirut, Dār al-țalīa, 1971, p. 140.

55 Al-Azraqī, Ahbār Makka, p. 362 ( ${ }^{\circ}$ 296).

56 'Abd al-Razzāq, al-Mușannaf, v, p. 89 (nº 9088); Hūd b. Muhakkam al-Hawwārī, Tafsìr Kitāb Allāh al-'azīz, ed. Bālhāğğğ b. Sa'īd al-Šarîfì, Beirut, Dār al-gàarb al-islāmī, 199o, I, p. 146. Elsewhere, the two components of this report appear separately: al-Azraqī, Ahbār Makka, p. 358, 362 (n ns $\left.^{\text {289 }}, 297\right)$. This report may have emerged as an exegesis of God's command to "purify my house" (țahhirā baytī) at Kor 2, 125. See: al-Samhūdī, Wafä al-wafā, II, p. 449; 'Abd Allāh b. al-Mubārak, Kitāb al-Zuhd wa-yalīhi Kitāb al-Raqā̄iq, ed. Ḥabīb al-Raḥmān al-A`ẓamī, Beirut, Dār al-kutub al-'ilmiyya, 1980, p. 415 (nº 1176) [recension of al-Ḥusayn al-Marwazī]. 
Gifting light and scent for the sacred space at Jerusalem is praised in a widely-attested Prophetic hadit. Equating the gift with pilgrimage itself, the Prophet Muhammad states that those who are unable to travel to Jerusalem should send oil to light the lamps on the Temple Mount and "it will be as if you had prayed there. ${ }^{57}$ While the Prophet's words most explicitly address the visual beautification of Jerusalem's sacred space through light, it is worth noting that the lamps provided not only light, but scent as well. This dual role is reflected in reports that, during the caliphate of 'Abd al-Malik, the Temple Mount was lit with lamps burning oils of ben-tree and jasmine, which the building's attendants would also use to perfume themselves. ${ }^{58}$

A vivid depiction of an aromatic gift made to a relatively minor pilgrimage site appears in a report about the grave shrine of the Companion Talha b. 'Ubayd Allāh in Bașra. Here, a woman visiting Ṭalha's grave empties the entirety of a bottle of ben-tree oil upon the grave, pouring it out "until the soil of the grave reeked of musk."59 This report—and others like it—suggest that gifts of scent offered Muslims a tangible means of venerating several pilgrimage destinations.

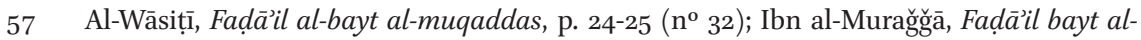
maqdis wa-l-ḩalïl, p. 88, 141-142 (n ${ }^{\text {os }} 79$, 178-179); Muḥammad b. 'Umar al-Wāqidī, Kitāb al-Maḡāzī, ed. Marsden Jones, London, Oxford University Press, 1966, II, p. 866; Ibn Māğa, Sunan, ed. Baššār 'Awwād Márūf, Beirut, Dār al-ğ̄il, 1998, II, p. 522 (nº 1407); Abū Dāwūd Sulaymān b. al-Ašcaț al-Azdī l-Siǧistānī, Kitāa al-Sunan, ed. Muhammad 'Awwāma, Jeddah, Dār al-qibla li-l-țaqāfa l-islāmiyya, 1998, I, p. 371 (no 458); Aḥmad b. Ḥanbal, Musnad al-Imām Aḥmad b. Hanbal, eds Šu'ayb al-Arna'ūț, 'Ādil Muršid, et al., Beirut, Mu’assasat al-risāla, 1995-2001, XLV, p. 597-599 (n ${ }^{\text {os }}$ 27626-27627); Abū Yalā, Musnad, XII, p. 523 (no 7088); Sulaymān b. Aḥmad al-Ṭabarānī, al-Mu ǧam al-kabìr, ed. Ḥamdī 'Abd al-Mağīid al-Salafi, Cairo, Maktabat Ibn Taymiyya, n.d., xxv, p. 32-34 (n ${ }^{\text {os }} 54-56$ ); id., Musnad al-šāmiyyinn, ed. Ḥamdī 'Abd al-Mağīd al-Salafì, Beirut, Mu’assasat al-risāla, 1989, I, p. 197, 271 ( $\left.{ }^{\text {os }} 344,471-472\right)$; III, p. 137 (nº 1947); Ibn Abī 'Āṣim al-Ḍaḥhāk al-Šaybānī, al-Āhāàd wa-l-mațānī, ed. Bāsim Fayṣal Aḥmad al-Ǧawābira, Riyadh, Dār al-rāya, 1991, vI, p. 216 ( ${ }^{\circ}$ 3448); Šams al-Dīn al-Dֵahabī, Mīzān al-ítidāl fìnaqd al-riğāl, ed. Muhammad Riḍ̂ān 'Irqsūsī, Beirut, Dār al-risāla l-ālamiyya, 20o9, II, p. 83 (nº 2814); Ǧamāl al-Dīn Yūsuf al-Mizzī, Tahdī̄b al-kamāl fì asmā’ al-riğāl, ed. Baššār 'Awwād Ma'rūf, Beirut, Mu’assasat al-risāla, 1985, IX, p. 481-483. On this tradition, see: Ignaz Goldziher, Muslim Studies, eds and transl. Samuel Miklos Stern and Christa Renate Barber, London, Allen \& Unwin, 19671971, I, p. 45; Elad, Medieval Jerusalem, p. 64; Raby, "In Vitro Veritas," p. 178.

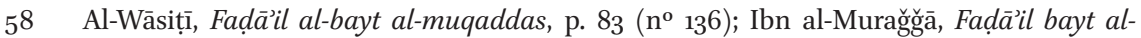
maqdis wa-l-ḩalīl, p. 6o-61; Muğīir al-Dīn, al-Uns al-ğalīl, I, p. 404; al-Suyūṭī, Ithāâf al-Ahișșā, I, p. 244; Elad, "Why Did 'Abd al-Malik," p. 36; Kaplony, The Haram of Jerusalem, p. 328; Raby, "In Vitro Veritas," p. 177.

59 Ibn 'Abd Rabbihi, al-Iqdal-farìd, v, p. 70-71. On veneration of Țalha's grave, see: Adam Bursi, "A Holy Heretical Body: Țalḥa b. 'Ubayd Allāh's Corpse and Early Islamic Sectarianism," Studies in Late Antiquity, 2/2 (2018), p. 147-179. 
Even if these descriptions of the overwhelming odiferousness of these spaces might be (in some cases) pious exaggerations, the perfumes nonetheless left olfactory traces upon the pilgrims themselves. As noted above, the odor of the Dome of the Rock reportedly clung to its visitors after they left the site, such that "one who smells of its scent, they say of him, "This is one of those who have entered the Șahra." At the Ka'ba, the building's perfume stained visitors' clothes when they touched it, leading early jurists to ask whether contact with the perfume necessitated a ritual ablution. ${ }^{60}$ Some jurists were wary of the perfume and its scent, but others suggested that there was no need to wash off the Kaba's perfume, with some even going so far as to say that the perfume was tahür ("pure, purifying") rather than ritually contaminating. ${ }^{61}$ Illustrative of a relatively permissive attitude - and of the perfume's pervasiveness - are the words of the Mālikī jurist 'Abd al-Raḥmān b. al-Qāsim al-'Utaqī (d. 191/8o6): when asked if any expiation was required for those who "touch the halüq of the Ka'ba," al-'Utaqi replied, "I hope it is merely a trivial thing [...] for whenever [people] enter the House, they can scarcely rid themselves of it [i.e. the perfume's smell]."62 Some Šìi hadit ț connect touching the Ka'ba's perfume with discussion of "the halūq of the [Prophet Muhammad's] tomb," suggesting that it was just as difficult for a pilgrim to avoid the latter's perfume as that of the

6o This was likely related to debates on the acceptability of wearing scent while in ihrām. See discussion below.

61 Ibn Abī Šayba, al-Mușannaf, v, p. 247 (nos 13677-1368o); al-Fākihī, Ahbār Makka, I, p. 347 (n $\left.{ }^{\text {os }} 713-715\right)$; Muḥammad b. Ya'qūb al-Kulaynī, al-Käfì, ed. 'Alī Akbar al-Ġaffārī, Tehran, Dār al-kutub al-islāmiyya, 1968-1971, IV, p. 339; Ibn Bābawayh al-Qummī, Kitāb Man lā yaḥ̣̂uru l-faqīh, ed. Ḥusayn al-A'lamī, Beirut, Mu’assasat al-a'lamī li-l-mațbūāt, 1986, II, p. 226 (no 2613); Muḥammad b. al-Ḥasan al-Ṭūsī, Tahd̄īb al-aḥkām fì šarh al-Muqni'a li-l-šayh al-Mufid, ed. Muḥammad Ǧáfar Šams al-Dīn, Beirut, Dār al-taāruf li-l-mațbūāt

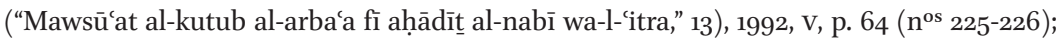
Muhibb al-Dīn al-Ṭabarī, al-Qirā li-qāṣid Umm al-Qurā, ed. Mușțafā l-Saqqā, Beirut, alMaktaba l-ilmiyya, n.d., p. 202.

62 Saḥnūn b. Saīì al-Tanūhūi, al-Mudawwana l-kubrā li-l-imām Mālik b. Anas al-Așbaḥī, Beirut, Dār al-kutub al-ilmiyya, 1994, I, p. 46o. Discussions also appear in: Muhammad b. Idrīs al-Šāfi'ì, al-Umm, ed. Rif'at Fawzī 'Abd al-Muțțalib, al-Manșūra, Dār al-wafā', 20o1, III, p. 380-381 (n ${ }^{\circ}$ 1080); Ibn Ḥazm al-Andalusī, al-Muhallā bi-l-ătāar, ed. 'Abd al-Ġaffār Sulaymān al-Bandārī, Beirut, Dār al-kutub al-'ilmiyya, 2003, v, p. 291-295 (nº 895); Ibn Abī Zayd al-Qayrawānī, al-Nawādir wa-l-ziyādāt 'alā mā fì l-Mudawwana min ġayrihāa min al-ummahāt, ed. 'Abd al-Fattāḥ Muḥammad al-Ḥulw, Beirut, Dār al-g̉arb al-islāmī, 1999, II, p. 351. On early debates about entering the Ka'ba, see: Gerald R. Hawting, "We Were Not Ordered with Entering It but Only with Circumambulating It': Hadith and Figh on Entering the Kaba," Bulletin of the School of Oriental and African Studies, 47/2 (1984), p. 228-242. 
Kaba. ${ }^{63}$ Scent therefore not only characterized the pilgrimage space itself, but also displayed one's status as pilgrim by sensually marking one's body and clothes.

Indeed, the role of scent at these locations extended further than passive inhalation or absorption, for pilgrims in some cases physically collected and/ or imbibed these places' smells as a sort of pilgrimage souvenir. Material evidence suggests that Muslims from the first/seventh century onwards collected scented contact relics from several pilgrimage sites. For example, late antique glass souvenir bottles from Jerusalem may have "served as containers for the halūq that had been used to anoint the Șahra." ${ }^{64}$ Bearing an image of 'Abd al-Malik, these containers of perfume created an association between the sacred space of the Dome of the Rock, its scent, and the caliph's politicoreligious authority. ${ }^{65}$ These objects point to the place of scent in the Umayyad effort to patronize the Dome of the Rock as a sacred pilgrimage space.

While archaeological sources provide only hints of these practices, literary sources explicitly describe early Muslims collecting materials from pilgrimage spaces, with sweet scent often appearing as a key aspect of these materials' importance. Visitors to the grave of the martyr 'Abd Allāh b. Gālib (d. 83/702) in Bașra perfumed their clothes with the grave's miraculously musk-scented

63 Ibn Bābawayh, Kitāb Man lā yahduru, II, p. 225-226 (nº 2612); al-Ṭūsī, Tahd̄īb al-aḥkām, v, p. $272\left(n^{\circ} 1016\right)$. Only significantly later texts specify that the tomb mentioned here is that of the Prophet Muhammad: Muhammad Taqī l-Mağlisī, Raw dat al-muttaqīn fì šarh Man lā yaḥ̣uruhu l-faqīh, Qom, Dār al-kitāb al-islāmī, 2008, viıI, p. 84; Yūsuf b. Aḥmad

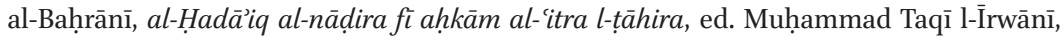
Beirut, Dār al-ạ̣wā', 1985-1989, Xv, p. 420; al-Sayyid 'Alī b. al-Sayyid Muḥammad 'Alī l-Ṭabāțabāìi, Riyāẹ al-masā̉il fì taḥqūq al-aḥkām bi-l-dalā̉il, Qom, Mu’assasat Âl al-bayt li-ihyā̄ al-turāt, 1998, viı, p. 434.

64 Raby, "In Vitro Veritas," p. 175. Archaeological evidence suggests Muslims' collection of such materials also from the Kathisma church south of Jerusalem and the shrine of St. Sergius in the Syrian town of Rușāfa. See: Rina Avner, "The Kathisma: A Christian and Muslim Pilgrimage Site," Aram, 18-19 (2006-2007), p. 547; Dorothea Weltecke, "Multireligiöse Loca Sancta und die mächtigen Heiligen der Christen," Der Islam, 88/1 (2012), p. 81-82; Elizabeth Key Fowden, The Barbarian Plain: Saint Sergius between Rome and Iran, Berkeley-Los Angeles-London, University of California Press ("The Transformation of the Classical Heritage," 28), 1999, p. 38, 85-86. Though we do not have direct evidence of scenting of the materials collected from these sites, these objects suggest early Muslims' participation in the world of late antique Near Eastern pilgrimage practices, in which the perfuming of pilgrimage souvenirs was extremely common.

65 Raby, "In Vitro Veritas," p. 115-127, 181. For another interpretation of the image, see: Robert Hoyland, "Writing the Biography of the Prophet Muhammad: Problem and Solutions," History Compass, 5/2 (2007), p. 581-602. 
soil, ${ }^{66}$ while Šìi tomb at Karbalä ${ }^{67}$ Texts often present the scents as autochthonous manifestations of these locations' holiness. However, one finds a more terrestrial explanation for the odor of such sacred materials in a Šìi report in which the Imam Muhammad al-Bāqir (d. 114/733) tells a follower:

Take some of the soil of Husayn's tomb, knead it with rain water, and mix it with honey and saffron. Divide it among the Ší a so that they might heal their sick with it. ${ }^{68}$

Here, honey and saffron add gustatory and olfactory dimensions to this pilgrimage relic, which Muhammad al-Bāqir advices should be "divided among the Šía," forming a sort of sensorial community associated with the practice of consuming this relic of Husayn's tomb.

These kinds of relic practices did not win universal approval within early Muslim circles, as evidenced in the discussions in many early texts about using stones and soil from the Meccan Haram (the sacred area surrounding the Ka'ba) as blessings and medicinal objects. ${ }^{69}$ In these discussions, some

66 'Abd Allāh b. al-Mubārak, Kitāb al-Ǧ̆ihād, ed. Nazīh Ḥammād, Jeddah, Dār al-maṭbūāt al-ḥadīta, 1982, p. 140 (nº 144); Aḥmad b. Yahyyā l-Balādِurī, Ansāb al-ašrrāf, ed. Muḥammad al-Ya'lāwī, Beirut, Klaus Schwarz, 2002, vıI/II, p. 266; Abū Nu'aym al-Aṣfahānī, Hilyat al-awliyā’ wa-țabaqāt al-asfiyā', Cairo, Maktabat al-Hูānğī, 1996, II, p. 257-258; Aḥmad b. Muḥammad b. Ḥanbal, al-Zuhd, Beirut, Dār al-kutub al-ilmiyya, 1983, p. 302-303; Muḥammad b. Aḥmad b. Tamīm al-Tamīmī, Kitāb al-Mihan, ed. Yaḥyā Wahīb al-Ǧubūrī, Beirut, Dār al-ġarb al-islāmī, 20o6, p. 2o1; David Cook, Martyrdom in Islam, Cambridge-New York, Cambridge University Press ("Themes in Islamic History"), 2007, p. 116-119.

67 Ibn Qūlawayh, Kāmil al-ziyārāt, ed. Ǧawād al-Qayyūmī l-Ișfahānī, Qom, Našr al-Faqāha, n.d.,p.131, 143, 462-465, 474-479; Suzanne Evans, "The Scent of a Martyr," Numen, 49/2 (2002), p. 193-211; Marco Schöller, The Living and the Dead in Islam: Studies in Arabic Epitaphs. II: Epitaphs in Context, Wiesbaden, Harrassowitz, 2004, p. 90-99; Khalid A. Sindawi, "Holy Earth: The Importance of the Land of Karbala for the Shî‘ah," Islamic Culture, 77 (2003), p. $73-84$.

68 Aḥmad b. Muḥammad al-Barqī, Kitāb al-Mahāsin, ed. Sayyid Ğalāl al-Dīn al-Ḥusaynī, Qum, Dār al-kutub al-islāmiyya, n.d., p. 500 (nº 621); Ibn Qūlawayh, Kāmil al-ziyārāt, p. 461. On al-Barqī and his text, see: Roy Vilozny, "A Šīī Life Cycle according to al-Barqìis Kitāb al-Mahâsin," Arabica, 54/3 (2007), p. 362-396. Regarding the date of the beginning of Šìa pilgrimage to Husayn's tomb, see: Torsten Hylén, "Myth, Ritual, and the Early Development of Shiite Identity," Intellectual History of the Islamicate World, 6/3 (2018), p. 300-331; Haider, The Origins of the Shĩa, p. 243-248.

69 On collecting stones and soil from the Ḥaram, see: 'Abd al-Razzāq, al-Muṣannaf, v, p. 145146 (n ${ }^{\text {os }}$ 9205-9209); Ibn Abī Šayba, al-Mușannaf, v, p. 388 (no 14545-14547); Abū Yūsuf Ya'qūb b. Ibrāhīm al-Anșārī, Ihtilā́f Abì Hạīfa wa-Ibn Abì Layla, ed. Abū l-Wafā’ al-Afğānī, Hyderabad, Mațbacat al-wafā' ("Lağnat ị̣yā' al-ma‘ārif al-nưmāniyya”), 1938, p. 139-140; 
authorities include the perfumes of the sacred buildings within the class of substances that should not be removed from the Haram. For example, the Kūfan scholar Sa'īd b. Ğubayr (d. 95/714) reportedly "found it detestable that some of the perfume $(t \bar{i} b)$ of the Ka'ba be taken in order to seek healing with it. When he saw the attendant (hädim) taking some of it, he would strike her, not failing to cause pain." ${ }^{70}$ The Šìì Imam Ğa far al-Ṣādiq (d. 148/765) similarly disapproved of these activities at the Ḥaram: when a man asks Ğafar, "My uncle swept the Ka'ba and took some of its soil, shall we heal with it?" Ğafar responds, "Return it there." When another returned pilgrim says that he has taken some of the sukk that had coated the Maqām Ibrāhìm near the $\mathrm{Ka}$ ba (alongside soil and pebbles from around the Ka'ba), Ğa far replies, "Don't do that!"71 This latter report suggests that, like the Ka'ba, the Maqām Ibrāhīm also was coated in perfume, in this case the musk-based mixture called sukk.72 Like the soil surrounding these structures, their perfumes were understood as materials that should not be removed from the Haram.

Other authorities, however, considered the Ka'ba's perfume as a permissibly transportable pilgrimage souvenir. Indeed, some of those jurists who specifically rejected taking objects such as stones and soil from the Haram apparently had no such qualms about the collection of the perfume. For example, while the Meccan jurist 'Ațā̄' b. Abī Rabāḥ (d. 115/733) considered taking stones and soil from the Haram detestable, ${ }^{73}$ he held that "there is no problem in taking away some of the perfume of the Ka'ba or its kiswa, with the permission of the attendants (hağaba)." ${ }^{74}$ Thus, while permitting the collection of these materials from the Ka'ba, 'Atạa' stipulates that one must seek "the permission of the attendants (hağaba)," suggesting that the distribution of the Ka'ba's perfume may have been among these officials' duties and a (semi?) sanctioned aspect of the pilgrimage rituals. ${ }^{75}$ Indeed, in a variant version, 'Ațā' commands: "Do not

al-Šāficī, al-Umm, viıI, p. 344-345 (n ${ }^{\text {os }} 3198$-320o); al-Azraqī, Ahbār Makka, p. 725-726 (nos 881-884); al-Fākihī, Ahbār Makka, III, p. 389-392 (nº 2273-2281).

$70 \quad$ Ibn Abī Šayba, al-Muṣannaf, v, p. 312 (nº 14093).

71 Al-Kulaynī, al-Kāfi, IV, p. 229; Ibn Bābawayh, Kitāa Man lā yaḥ̣̂uru, II, p. 169-70 (n ${ }^{\text {os } 2334-2336) . ~}$

72 On sukk, see: King, Scent from the Garden, p. 153, 156.

73 Ibn Abī Šayba, al-Mușannaf, v, p. 388 (nº 14547); al-Fākihī, Ahbār Makka, III, p. 39o-391 (no 2276-2278).

74 Al-Fākihī, Ahbār Makka, I, p. 348 (nº 716).

75 On 'Ațā’s role in giving rulings during the hağğ, see: Muhammad Qasim Zaman, Religion and Politics Under the Early 'Abbāsids: The Emergence of the Proto-Sunnī Elite, Leiden, Brill ("Islamic History and Civilization," 16), 1997, p. 149, n. 103. 
rub off perfume from the House unless it is given to you," indicating that some such figure existed with the authority to distribute the material to pilgrims. ${ }^{76}$

A distinction between soil and perfume appears again a century later in opinions attributed to Ahmad b. Hanbal (d. 241/855). In response to a question about taking soil from the Haram, Ibn Hanbal answers, "No [...] Do not remove anything from Mecca," but concedes, "as for the perfume (al-țīb), it eases digestion (ashala), and there is no problem with the water of Zamzam." "77 Like 'Ațā', Ibn Hanbal suggests that taking perfume from the Ka'ba is acceptable and has medicinal value: he compares the perfume to water from Zamzam, a substance that was renowned for its healing abilities and commonly collected by pilgrims to Mecca. ${ }^{78}$ Indeed, Ibn Hanbal's contemporary (and persecutor), the Abbasid caliph al-Wātiq (r. 227/842-232/847), reportedly received both Zamzam water and halūq from the Ka'ba while on his deathbed. ${ }^{79}$

The statements attributed to 'Ațầ' and Ibn Hianbal suggest that the scent of the perfume-endowed with material sacrality through its haptic association with the Kaba—contained a healing power. The combined olfactory and haptic power of the Ka'ba's perfume is seen in another statement from 'Ațầ': "When one of us wants to seek healing with it, he will bring perfume and wipe the [Black] Stone with it, then take it." 80 A similar statement is attributed to Ibn Hanbal in later Hanbali figh sources: "If one wants to seek healing through the Ka'ba's perfume, do not take anything from [the Ka'ba], but rather spread perfume upon [the Kacba], then take it." ${ }^{\prime 1}$ Rather than taking from the perfume

76 Ibn Abī Šayba, al-Mușannaf, v, p. 312 ( $\mathrm{n}^{\circ}$ 14094). Clerical officials were similarly in charge of the distribution of such materials at late antique Christian pilgrimage sanctuaries: Caseau, "Experiencing the Sacred," p. 71.

77 Masāil al-imām Aḥmad riwāyat Abī Dāwūd Sulaymān b. al-Ašcaț al-Siğistānī, ed. Țāriq b. 'Awaḍ Allāh b. Muḥammad, Cairo, Maktabat Ibn Taymiyya, 1999, p. 187 (nºs 913-915).

78 In another recension of the Masāill, Ibn Hanbal does not mention the Ka'ba's perfume, but only Zamzam water: Masāil al-imām Ahmad b. Hanbal wa-Ishāa $b$. Rāhawayh bi-riwāyat Isḥāq b. Manșūr al-Marwazī, ed. Muḥammad b. 'Abd Allāh al-Zāḥim et al., Medina, al-Ǧāmía l-islāmiyya, 2004, v, p. 2307-2308 (nº 1593).

79 Ya'qūb b. Sufyān al-Basawī, Kitāb al-Márifa wa-l-ta'rīh, ed. Akram Ḍiyā' al-'Umarī, Medina, Maktabat al-dār, 1989, I, p. 209.

8o Ibn Abī Šayba, al-Mușannaf, v, p. 312 (nº 14093). Mention occurs elsewhere of perfume on the Black Stone: al-Fākihī, Aḩbār Makka, I, p. 129 (nº 128); Ibn Abī Zayd, al-Nawādir wa-l-ziyādāt, II, p. 351.

81 Muḥammad b. Muflị al-Maqdisī, Kitāb al-Furū', ed. 'Abd Allāh b. 'Abd al-Muḥsin al-Turkī, Beirut, Mu’assasat al-risāla, 2003, vi, p. 16-17; Muḥammad b. 'Abd Allāh al-Sāmirī, al-Mustaw'ib, ed. 'Abd al-Malik b. 'Abd Allāh b. Duhayš, Mecca, Maktabat al-Asadī, 2003, I, p. 494; Ibn Qudāma l-Maqdisī, al-Muğnī, eds 'Abd Allāh b. 'Abd al-Muḥsin al-Turkī and 'Abd al-Fattāḥ Muhammad al-Ḥulw, Riyadh, Dār ālam al-kutub, 1997, v, p. 464. 
that had already been used to anoint the Ka'ba, visitors are encouraged to create a new contact relic by touching perfume to the Ka'ba (or, in 'Ațā's case, to the Black Stone more specifically), thereby endowing the scented material with power that allows individuals to "seek healing through it." A mixture of scent and touch lies behind the healing power of the perfume: even if the scent itself does not originate from the Ka'ba, the perfume nevertheless contains a healing power as a result of its physical contact with the sacred building. Well situated within late antique and early medieval ideas about the medicinal powers of perfumes and odors-including scented contact relics such as soil and fluids collected from sacred locations - these reports attest to the general importance of scent in the experience of early Islamic sacred space. ${ }^{82}$

\section{$3 \quad$ Perfume and Paradise at Early Islamic Pilgrimage Spaces}

These sources suggest that scents occupied a prominent place within early Islamic pilgrimage. With all of this perfume and incense floating about, one might then ask: What was the significance of these scents for pilgrims to early Islamic sacred spaces? What meanings were conveyed to early Muslims by the presence of scents there? As noted at the beginning of this essay, the usages of perfume and incense by early Muslims have often been interpreted as largely synonymous with (if not directly dependent upon) the practices and beliefs of other Near Eastern religious communities. Along these lines, we might categorize the perfuming of the Dome of the Rock, the Kaba, and other early Islamic spaces as specific examples of general practices-known throughout

82 Mark Bradley (ed.), Smell and the Ancient Senses, London-New York, Routledge ("The Senses in Antiquity"), 2015; Richard Palmer, "Bad Odour: Smell and its Significance in Medicine from Antiquity to the Seventeenth Century," in Medicine and the Five Senses, eds William F. Bynum and Roy Porter, Cambridge, Cambridge University Press, 1993, p. 61-68; Béatrice Caseau, "Parfum et guérison dans le christianisme ancien et byzantine: des huiles parfumées des médecins au myron des saints byzantins," in Les pères de l'église face à la science médicale de leur temps, eds Véronique Boudon-Millot and Bernard Bouderon, Paris, Beauchesne ("Théologie historique," 117), 2004, p. 141-91; ead., "Incense and Fragrances: From House to Church. A Study of the Introduction of Incense in the Early Byzantine Christian Churches," in Material Culture and Well-Being in Byzantium (400-1453), eds Michael Grünbart, Ewald Kislinger, Anna Muthesius, and Dionysios Ch. Stathakopoulos, Vienna, Österreichische Akademie der Wissenschaften ("Denkschriften: Österreichische Akademie der Wissenschaften. Philosophisch-historische Klasse," 356; "Veröffentlichungen zur Byzanzforschung," 11), 2007, p. 75-92. 
the ancient (and modern) world - related to the provision of scents for areas associated with divinity or other sacred presences. ${ }^{83}$

However, in Aroma: The Cultural History of Smell, Constance Classen, David Howes, and Anthony Synnott write: "Sacred rites of smell are common to many people $[\ldots]$. These olfactory rites are similar on one level, yet each has a unique meaning within the context of the particular culture which practises it." ${ }^{84}$ Even within late antiquity, the significance attached to the use of incense, for example, was not static, but varied across time and place among different Near Eastern communities. While early Christians rejected as idolatrous any connections between the burning of incense and sacrifices to (or communication with) God, "the idea of propitiatory incense re-emerged" and became pervasive in the cult of saints and elsewhere in the practices of different late antique Christian communities by the fourth and fifth centuries. ${ }^{85}$ In late antique Judaism, the lighting of incense might evoke sentiments of penitence and atonement connected with the Temple rituals described in biblical texts, but was also looked upon skeptically as a potentially idolatrous and/or magical practice, and the acceptability of burning incense in synagogues and during religious ceremonies was thus a point of debate among different Jewish communities. ${ }^{86}$ Thus, even if "practically everywhere odiferous substances are employed to communicate with the gods," ${ }^{87}$ these materials convey different meanings to different audiences, due to the ways in which "olfactory

83 David Howes, "Olfaction and Transition: An Essay on the Ritual Uses of Smell," Canadian Review of Sociology, 24/3 (1987), p. 400, 403; Gale Peter Largey and David Rodney Watson, "The Sociology of Odors," American Journal of Sociology, $77 / 6$ (1972), p. 1031; Dan Sperber, Rethinking Symbolism, transl. Alice L. Morton, Cambridge, Cambridge University Press ("Cambridge Studies in Social Anthropology," 11), 1975, p. 118; Plate, A History of Religion, p. 61-97; Mark M. Smith, Sensory History, Oxford-New York, Berg, 2007, p. 6o-63.

84 Constance Classen, David Howes, and Anthony Synnott, Aroma: The Cultural History of Smell, London-New York, Routledge, 1994, p. 130-131.

85 Caseau, "Incense and Fragrances," p. 92; Harvey, Scenting Salvation, p. 58, 75-83; Vikan, Early Byzantine Pilgrimage, p. 50-52.

86 Deborah A. Green, The Aroma of Righteousness: Scent and Seduction in Rabbinic Life and Literature, University Park, Pennsylvania State University Press, 2011; Steven Fine, This Holy Place: On the Sanctity of the Synagogue during the Greco-Roman Period, Notre Dame, University of Notre Dame Press ("Christianity and Judaism in Antiquity," 11), 1997, p. 8485; Richard A. Freund, Digging Through the Bible: Understanding Biblical People, Places, and Controversies through Archaeology, Lanham, Rowman \& Littlefield, 2009, p. 236-246; Abraham O. Shemesh, "Those who Require '[...] the Burning of Incense in Synagogues are the Rabbinic Jews': Burning Incense in Synagogues in Commemoration of the Temple," HTS Teologiese Studies/Theological Studies, 73/3 (2017).

87 Howes, "Olfaction and Transition," p. 403. 
communication is 'coded" through social and cultural expectations. ${ }^{88}$ In short, "there can be no such thing as a natural history of the senses, only a social history of human sense perception." 89

What social meaning and significance might early Muslims have perceived, then, from the perfume and incense that they encountered at pilgrimage destinations? I suggest that we might understand how early Muslims "read" these odors by considering the close connections between sacred space, paradise, and pleasant scent within early Islam. Early Islamic sources strongly correlate terrestrial sacred spaces with heavenly paradise, often going so far as to say that these locations "are paradise, or rather, 'one of its gardens."'90 As art historians have noted, the decorative motifs at several of these spaces suggest conscious efforts to evoke multisensory experiences of heaven on earth. Given the strongly olfactory descriptions of paradise that characterize early Islamic traditions, the perfumes that covered and filled many sacred spaces likely evoked a sensorial connection with paradise and thus a sense of experiencing paradise itself at the pilgrimage site.

Several scholars have taken note of connections in early Islamic texts between sacred spaces—especially pilgrimage sites—and paradise. Brannon Wheeler has drawn attention to the mythological connections between the hağğ and the story of Adam's fall from paradise, arguing that the establishment of the sanctuary in Mecca and the institution of the pilgrimage rites there served as "an earthly substitute for the garden of Eden." 91 Stephen R. Burge has focused on "the role of angels in the articulation of sacred space in Islam," examining stories in which "the rites associated with the pilgrimage and the

88 Classen, Howes, and Synnott, Aroma, p. 3. See also: Kelvin E.Y. Low, "Ruminations on Smell as a Sociocultural Phenomenon," Current Sociology, 53/3 (2005), p. 397-417; Trygg Engen, Odor Sensation and Memory, New York-London, Praeger, 1991, p. 3.

89 Robert Jütte, A History of the Senses: From Antiquity to Cyberspace, transl. James Lynn, Cambridge-Malden, Polity Press, 2005, p. 9.

90 Christian Lange, Paradise and Hell in Islamic Traditions, New York, Cambridge University Press, 2016, p. 254.

91 Brannon M. Wheeler, Mecca and Eden: Ritual, Relics, and Territory in Islam, Chicago, University of Chicago Press, 20o6, p. 64, 86. See also: Katz, "The Hajj," p. 110-113. Peter Webb has recently argued that traditions of Adam's involvement in the beginnings of the Ka'ba and the hağğ date only from the third/ninth century and later: "The Hajj before Muhammad: Journeys to Mecca in Muslim Narratives of Pre-Islamic History," in The Hajj: Collected Essays, eds Venetia Porter and Liana Saif, London, The British Museum Press ("Research Publication," 193), 2013, p. 6-14. Note, however, that such traditions about Adam occur already in 'Abd al-Razzāq, al-Muṣannaf, v, p. 91-94, 116 (n os 9o9o, 9o92, 9096, 9118) and in Muḥammad b. Isḥāq, Kitāb al-Siyar wa-l-mag்āzī [recension of Yūnus b. Bukayr], ed. Suhayl Zakkār, Damascus, Dār al-fikr, 1978, p. 94-95, indicating that they circulated earlier than Webb argues. 
Kaba are those performed in heaven by the angels." ${ }^{m 2}$ Ofer Livne-Kafri and others have collected reports that associate Jerusalem (and especially the Sahra) with paradise and with early Islamic eschatological expectations. ${ }^{93}$ Heribert Busse has pointed to traditions sacralizing the Prophet's Mosque in Medina, where the space near the Prophet's tomb is said to be "one of the gardens of paradise" and the Prophet's minbar is said to stand atop the Pool (hawd) of paradise. ${ }^{94}$ Analyzing traditions associated with all of these locations, Christian Lange has argued that early texts describe the proximity of paradise at these sacred spaces not as "referential," symbolic, or "gesturing towards an otherworld that is absent," but rather as "truly and fully here on earth" and "indicat[ing] presence, not likeness." ${ }^{95}$ Placed together, these texts suggest that many early Muslims understood and experienced the sacredness of pilgrimage spaces as (symbolically or literally) related to paradise.

Paradisiacal themes have also been noticed by scholars of early Islamic art and architecture, who argue that the iconographic programs at some of these sites seem to have been designed with precisely such ideas in mind. According to Priscilla Soucek, Myriam Rosen-Ayalon, and others, the wall mosaics within the Dome of the Rock- filled with depictions of plants, trees, and precious stones - strongly mirror Near Eastern imagery of Paradise, including that found within the Qurān. ${ }^{96}$ The Prophet's Mosque at Medina offered similar

92 Stephen R. Burge, "Angels, Ritual and Sacred Space in Islam," Comparative Islamic Studies, 5/2 (2009), p. 221-245.

93 Ofer Livne-Kafri, "Jerusalem in Early Islam: The Eschatological Aspect," Arabica, 53/3 (2006), p. 382-403; id., "Jerusalem: The Navel of the Earth in Muslim Tradition," Der Islam, 84/1 (2008), p. 46-72; id., "The Muslim Traditions 'In Praise of Jerusalem' (Fad̄àil al-Quds): Diversity and Complexity," Annali dell'Università degli Studi di Napoli "L'Orientale", 58 (1998), p. 165-192; Izhak Hasson, "The Muslim View of Jerusalem: The Qurān and Hiadìth," in The History of Jerusalem: The Early Muslim Period, 638-1099, eds Joshua Prawer and Haggai Ben-Shammai, Jerusalem, Yad Izhak Ben-Zvi, 1996, p. 349-385; Josef van Ess, "Abd al-Malik and the Dome of the Rock: An Analysis of Some Texts," in Bayt al-Maqdis, eds Raby and Johns, p. 89-103; Necıpoğlu, "Dome of the Rock as Palimpsest," p. 28-30, 33-35.

94 Heribert Busse, "Die Kanzel des Propheten im Paradiesesgarten," Die Welt des Islams, 28/1-4 (1988), p. 99-111. See also: Josef van Ess, Theology and Society in the Second and Third Centuries of the Hijra: A History of Religious Thought in Early Islam, Volume 4, transl. Gwendolin Goldbloom, Leiden-Boston, Brill ("Handbook of Oriental Studies. Section 1, The Near and Middle East," 116/4), 2019, p. 613; Lange, Paradise and Hell, p. 250; Gautier H.A. Juynboll, Encyclopedia of Canonical Hadīth, Leiden-Boston, Brill, 2007, p. 313; Bisheh, The Mosque of the Prophet at Madinah, p. 275-276; Barbara Finster, "Die Mosaiken der Umayyadenmoschee von Damaskus," Kunst des Orients, 7 (1970-1971), p. 135; Schöller, The Living and the Dead, p. 48-50.

95 Lange, Paradise and Hell, p. 245.

96 Priscilla Soucek, "The Temple of Solomon in Islamic Legend and Art," in The Temple of Solomon: Archaeological Fact and Medieval Tradition in Christian, Islamic, and Jewish 
visual experiences explicitly connected with paradise, as we learn from an early report about the reconstruction of the mosque during the reign of the Umayyad caliph al-Walīd b. 'Abd al-Malik: "One of the craftsmen who worked on the mosaics said, 'We made them according to the images of the trees and palaces of Paradise that we found."'97 This caliph also decorated the Sacred Mosque in Mecca with mosaics, which Barbara Finster suggests "probably represented 'scenes of Paradise' as in the Prophet's mosque in Medina." 98 Although less directly apparent than this mosaic imagery, representations of heaven were also visible in the architecture of the Kacba, which early traditions characterize as a terrestrial version of the heavenly "Frequented House" (al-Bayt al-ma'mür) constructed "on the pattern of God's throne" (wizānat 'arš Alläh), ${ }^{99}$ and in that of the Dome of the Rock, several design features of which have been understood to "symbolize paradise."100 The decorative and architectural designs of these buildings thus offered visual manifestations of, or references to, paradise, enabling a direct experience of the divine at an earthly site.

Art, ed. Joseph Gutmann, Missoula, Scholar's Press ("Religion and the Arts," 3), 1976, p. 73-123; Myriam Rosen-Ayalon, The Early Islamic Monuments of al-Haram al-Sharîf: An Iconographic Study, Jerusalem, Hebrew University of Jerusalem Institute of Archaeology ("Qedem," 28), 1989, p. 46-69; Raya Shani, "The Iconography of the Dome of the Rock," Jerusalem Studies in Arabic and Islam, 23 (1999), p. 158-207; Finster, "Die Mosaiken der Umayyadenmoschee von Damaskus," p. 117-121; Finbarr Barry Flood, The Great Mosque of Damascus: Studies on the Makings of an Umayyad Visual Culture, Leiden-Boston-Köln, Brill ("Islamic History and Civilization. Studies and Texts," 33), 2001, p. 15-56; Necipoğlu, "Dome of the Rock as Palimpsest," p. 54-56; George, "Paradise or Empire," p. 53-55. Mathieu Tillier has recently drawn attention to the eschatological content of the inscriptions displayed within the Dome of the Rock: “Abd al-Malik, Muhammad et le Jugement dernier: le dôme du Rocher comme expression d'une orthodoxie islamique," in Les vivants et les morts dans les sociétés médiévales: actes du XLVIII Congrès de la SHMESP (Jérusalem, 2017), Paris, Éditions de la Sorbonne ("Publications de la Sorbonne. Histoire ancienne et médiévale," 158), 2018, p. 341-365.

97 Kitāb al-Manāsik, p. 365; Ibn al-Nağğār, al-Durra l-țamina, p. 176; al-Samhūdī, Wafă al-wafā, II, p. 27o. Discussed in: Jean Sauvaget, La Mosquée Omeyyade de Médine: étude sur les origines architecturales de la mosquée et de la basilique, Paris, Vanoest, 1947, p. 8o81; Finster, "Die Mosaiken der Umayyadenmoschee von Damaskus," p. 120, 133; George, "Paradise or Empire," p. 53.

98 Barbara Finster, "The Material Culture of Pre- and Early Islamic Arabia," in A Companion to Islamic Art and Architecture, eds Finbarr Barry Flood and Gülru Necıpoğlu, Hoboken, Wiley Blackwell ("Blackwell Companions to Art History," 12), 2017, I, p. 83; ead., "Die Mosaiken der Umayyadenmoschee von Damaskus," p. 129-131.

99 'Abd al-Razzāq, al-Muṣannaf, v, p. 28-29 (nºs 8873-8875); al-Azraqī, Ahbār Makka, p. 90 ff.; Livne-Kafri, "Navel of the Earth," p. 62-64.

100 Kaplony, The Haram of Jerusalem, p. 332; Heribert Busse, "Zur Geschichte und Deutung der frühislamischen Harambauten in Jerusalem," Zeitschrift des Deutschen Palästina-Vereins, 107 (1991), p. 149 . 
Heaven was available not only to the eye at these locations, but also to touch. Drawing upon Rosen-Ayalon's analysis of the Dome of the Rock's marble paneling "evoking the image of rippling water,"101 Alain George has argued:

The marble paneling below the mosaics, with its wave patterns, might have evoked water sliding down from this fantastical garden [...] a visual impression reinforced by their coolness to the touch [...]. In this reading, the monument offers an almost tactile glimpse of paradise on earth. ${ }^{102}$

A similar haptic connection with paradise was available to the Ka'ba's visitors when they touched the Black Stone, which early traditions describe as a jewel from Heaven and the right hand of God upon earth. ${ }^{103}$ Though later than the period under discussion here, the account of the Spanish pilgrim Muhammad b. Aḥmad b. Ğubayr (d. 614/1217) provides an idea of what experiencing the Stone was perhaps like for its visitors when he writes that: "The Stone, when kissed, has a softness and moistness which so enchants the mouth that he who puts his lips to it would wish them never to be removed."104 Such haptic encounters enabled a physical experience of heaven's touch, facilitating a visceral understanding of these locations as paradisiacal.

If paradise was seen and felt at these locations, scent offered another important axis through which this otherworld was made sensorially present for early Muslim pilgrims. A variety of texts manifest a strong correlation within the early Islamic imaginary between pleasant scents and paradise. As Anya King writes, while "the association of good fragrance with paradise has a long history" within the religious traditions of the Near East, Islamic literature displays a pronounced emphasis on this olfactory aspect of the afterlife that is "greatly expanded and elaborated by numerous references to specific aromatics,"

\footnotetext{
101 Rosen-Ayalon, Early Islamic Monuments, p. 55 .

102 George, "Paradise or Empire," p. 47-48. See also: Marcus Milwright, "Waves of the Sea': Responses to Marble in Written Sources (Ninth-Fifteenth Centuries)," in The Iconography of Islamic Art: Studies in Honour of Robert Hillenbrand, ed. Bernard O'Kane, Edinburgh, Edinburgh University Press, 2007, p. 211-221.

103 'Abd al-Razzāq, al-Mușannaf, v, p. 38-40 (n ${ }^{\text {os }}$ 8914-8922); Ibn Isḥāq, Kitāa al-Siyar wa-l-maḡāzī, p. 96; al-Azraqī, Ahbār Makka, p. 443-456 (n $\left.{ }^{\text {os }} 409-443\right)$; al-Fākihī, Ahbār Makka, I, p. 81-97 (n ${ }^{\text {os }} 1-33$ ); Katz, “The Hajj," p. 125; Juan Eduardo Campo, "Authority, Ritual, and Spatial Order in Islam: The Pilgrimage to Mecca," Journal of Ritual Studies, 5/1 (1991), p. 75 .

104 Muḥammad b. Aḥmad b. Ğubayr, Riḥlat Ibn Ğubayr, Beirut, Dār Ṣādir, 1964, p. 67. Translation from: Shalem, "Four Faces," p. 148.
} 
particularly musk, ambergris, camphor, and saffron. ${ }^{105}$ The Qurān mentions that paradise's blessed inhabitants drink pure water mixed with camphor $($ Kor 76,5$)$ and ginger $($ Kor 76,17$)$, as well as wine sealed with musk (Kor 83, 25-26). ${ }^{106}$ Early hadit texts embellish this olfactory image in descriptions of the heavenly scents of paradise and its residents: the soil of paradise is composed of saffron and musk, upon which the residents of the Garden lounge; the transformed heavenly bodies of these blessed individuals are said to exude a musk-like scent instead of the sweat or spit that they had produced in life; and the bodies of their paradisiacal companions, the hüriss, are composed from musk, camphor, and saffron. ${ }^{107}$ Smell is so implicated in the idea of paradise that many traditions frame the experience of the afterlife in terms of its scent: it is predicted that damned individuals "will not smell the scent of the Garden," while a soon-to-be martyr exclaims on the verge of his victorious death, "The Garden! By God I smell it!"108

The presence of these scented products on earth is itself traced directly to paradisiacal origins in traditions describing Adam's descent from heaven. After Adam's landing in India with the "smell of paradise" still upon him, this smell then "hung upon India's trees and valleys and filled the space with perfume."109 The rich scents of musk, ambergris, saffron, camphor, and aloeswood—all

105 King, Scent from the Garden, p. 272-273, 340-342, 352-356. For the association of paradise with scents in other Near Eastern traditions, see: Harvey, Scenting Salvation, p. 48-56, 88, 226, 235-239; Green, Aroma of Righteousness, p. 119-123, 164-165, 204-205; Caseau, "Incense and Fragrances," p. 83, 86-87.

106 Ailin Qian, "Delights in Paradise: A Comparative Survey of Heavenly Food and Drink in the Quran," in Roads to Paradise: Eschatology and Concepts of the Hereafter in Islam, eds Sebastian Günther and Todd Lawson, Leiden-Boston, Brill ("Islamic History and Civilization," 136), 2017, I, p. 251-270; Nerina Rustomji, The Garden and the Fire: Heaven and Hell in Islamic Culture, New York, Columbia University Press, 2009, p. 70; Lange, Paradise and Hell, p. 44, 66.

107 'Abd al-Razzāq, al-Mușannaf, xI, p. 413-424 (n ${ }^{\text {os }}$ 20866-20898); Ibn al-Mubārak, al-Zuhd, p. 521-538 (n $\left.{ }^{\text {os }} 1478-1537\right)$ [recension of al-Ḥusayn al-Marwazī], p. 66-82 (n ${ }^{\text {os }} 227-285$ ) [recension of Nu'aym b. Ḥammād]; 'Abd al-Malik b. Ḥabīb, Wașf al-firdaws, ed. Sa'd Karīm, Alexandria, Dār Ibn Haldūn, n.d., p. 16, 27-41, 69-72 (nºs 35, 62-104, 173-185); Ibn Qūlawayh, Kāmil al-ziyārāt, p. 204-205; Aziz Al-Azmeh, "Rhetoric for the Senses: A Consideration of Muslim Paradise Narratives," Journal of Arabic Literature, 26/3 (1995), p. 215-231; Rustomji, Garden and the Fire, p. 72, 84, 88, 89, 96, 111, 116; Ergin, "Fragrance of the Divine," p. 72.

108 Ibn Abī Šayba, al-Muṣannaf, IX, p. 208-209 (n ${ }^{\text {os }}$ 28505-28508); Ibn Sacd, Ṭabaqāt, I/II, p. 142; Aḥmad b. Yaḥyā l-Balād̂urī, Futūḥ al-buldān, eds 'Abd Allāh Anīs al-Ṭabbāc and 'Umar Anīs al-Ṭabbāc', Beirut, Mu’assasat al-ma'ārif, 1987, p. 635; Rustomji, Garden and the Fire, p. 17, 82; King, Scent from the Garden, p. 353.

109 Ibn Sa'd, al-Ṭabaqāt, I/I, p. 12; al-Ṭabarī, Tảrīh, I, p. 126; al-Kulaynī, al-Käfì, vi, p. 527-528; al-Fākihī, Ahbār Makka, I, p. 90 (nº 23); II, p. 43 (nº 1110); 'Abd al-Razzāq, al-Muṣannaf, v, p. 116 (nº 9118); al-Azraqī, Ahbāar Makka, p. 56o-561 (nº 662); Ibn Isḥāq, Kitāb al-Siyar 
imported from around the Indian subcontinent-are thus "produced from the smell of paradise" or, alternatively, "the smell of Adam."110 Paradise's scent reportedly even remained upon the Ka'ba itself after Adam's original construction of the building in Mecca, until the rains of the Flood washed the "smell of Adam" from it. ${ }^{111}$

Given this highly articulated connection between perfume and paradise within early Islamic traditions, the sweet scents that covered and filled sacred spaces like the Dome of the Rock and the Ka'ba could readily evoke a sense of being within paradise, or at least in its direct proximity. Notably, the substances used to perfume these locations are exactly those that are said to characterize the smell of paradise in the texts mentioned above. As King writes, "use of aromatics associated with the Garden reinforced the link between this world and the next for the believer."112 By scenting these locations, early Muslims endowed these spaces with a sympathetic olfactory connection to paradise, in which "the supernatural aspects or 'holiness' of the place are not separated from the material or 'natural' aspects." 13

Several traditions suggest that heavenly odors at these sites offered "gobetweens $[. .$.$] between the otherworld and this world," providing some of the$ direct material presence of paradise on earth at these sacred spaces. ${ }^{114} \mathrm{~A}$ tradition related about the Umayyad governor of the Hiğāz (and later caliph) 'Umar b. 'Abd al-'Azìz (r. 99/717-101/720) states that while he was standing within the Ḥiğr in Mecca, he said:

Ismāil complained to God of the heat of Mecca. God revealed to him, "I will open a gate of paradise in the Hiğr. A breeze will blow on you from it until the Day of Judgement."115

wa-l-maġāzī, p. 95; al-Bayhaqī, Dalāil al-nubuwwa, II, p. 53; Wheeler, Mecca and Eden, p. 83-86; King, Scent from the Garden, p. 36o-361; Thurlkill, Sacred Scents, p. 154-155.

110 Anya H. King, "The Importance of Imported Aromatics in Arabic Culture: Illustrations from Pre-Islamic and Islamic Poetry," Journal of Near Eastern Studies, 67/3 (2008), p. 175-189.

111 Al-Azraqī, Ahbār Makka, p. 73-74.

112 King, Scent from the Garden, p. 354.

113 Angela K. Martin and Sandra Kryst, "Encountering Mary: Ritualization and Place Contagion in Postmodernity," in Places Through the Body, eds Heidi J. Nast and Steve Pile, London-New York, Routledge, 1998, p. 210.

114 Lange, Paradise and Hell, p. 7.

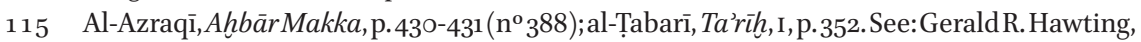
"The Origins of the Muslim Sanctuary at Mecca," in Studies on the First Century of Islamic Society, ed. Gautier H.A. Juynboll, Carbondale, Southern Illinois University Press ("Papers on Islamic History," 5), 1982, p. 43; id., "Plaything for Kings," p. 15. 
Here God is said to have created a "gate of paradise" that allowed its pleasantly-scented breeze (rawh) to blow directly into the Hiğr, the enclosed area next to the Kaba where the prophet Ismā'il is said to be buried. Similarly, it is reported that at Jerusalem:

From an open gate in the sky — one of the gates of Paradise — blessings and mercy descend upon Jerusalem [...] the dew that descends upon Jerusalem is a cure for every illness, as it comes from the blessings of Paradise. ${ }^{116}$

Another heavenly gate here allows "blessings and mercy" to fall upon Jerusalem, perhaps taking the form of the dew that is said to offer "a cure for every illness." This open connection between paradisiacal and earthly space is explicitly connected to scent in a Šìi report in which the Imam 'Alī b. al-Ḥusayn Zayn al'Ābidinn (d. 94/712 or 95/713) states that "each night an angel descends with three small pieces of the musk of the Garden, which he casts into the Euphrates," suggesting that the river's holiness for the Šīa is connected with literal pieces of heaven's sweet scent dissolved within it. ${ }^{117}$ The city of Medina, which before the Islamic Hiğra had exhibited a foul smell, began to display a "sweet scent of its soil" and a "fragrance of its air" after the Prophet Muhammad transformed it into a sacred space (haram): this scent was a divine sign ( $\bar{a} y a)$ from God, so pleasant that "there is nothing that surpasses it but the scent of paradise (rị al-ğanna)."118 At locations that contained pieces of paradise itself-such as the Black Stone and the Sahra-scent offered another material manifestation of paradise in pilgrims' midst.

The scent of the pilgrims themselves may have also been related to the experience of paradise offered at these locations. In his examination of connections between the Meccan hağğ and the garden of Eden, Wheeler argues that the "the prohibitions [...] pertaining to the sanctuary at Mecca and the conduct

116 Ibn al-Murağğā, Faḍāil bayt al-maqdis wa-l-halül, p. 149 (nº 19o), 264 (nº 399); Kaplony, The Haram of Jerusalem, p. 287.

117 Al-Kulaynī, al-Käfĭ, vI, p. 402; Ibn Qūlawayh, Kāmil al-ziyārāt, p. 108; Ibn 'Asākir, Ta’rīh madinat Dimašq, I, p. 213. On Šīi veneration of the Euphrates, see: Khalid A. Sindawi, "The Cult of the Euphrates and Its Significance among the Imāmī Shī‘a," Der Islam, 81/2 (2004), p. 249-269.

118 Al-Ǧāhị, Kitāb al-Hayawān, ed. 'Abd al-Salām Muhammad Hārūn, Cairo, Mușțafā l-Bābī l-Ḥalabī, 1965-1969, I, p. 247; III, p. 142. Cited in Munt, The Holy City of Medina, p. 89; Maher Jarrar and Nisrine Jaafar, "It Stinks in Basra!' Al-Jāḥiz on Odors," in Al-Jāhiz: A Muslim Humanist for Our Time, eds Arnim Heinemann, John L. Meloy, Tarif Khalidi, and Manfred Kropp, Würzburg-Beirut, Ergon Verlag-Orient-Institut (“Beiruter Texte und Studien," 119), 2009, p. 274. 
of pilgrims correspond directly to conditions in the garden of Eden" and, more specifically, that the prohibition against wearing scent during the hağğ rituals "may be linked with the notion that all perfume originated from the plants of the garden of Eden and as such did not exist before the fall."119 In fact, although this prohibition was adopted by the classical Islamic legal schools, wearing scent during hağğ was a debated practice in the first centuries, with many early jurists permitting it during at least certain parts of the ritual. ${ }^{120} \mathrm{In}$ one report, the Umayyad caliph Sulaymān b. 'Abd al-Malik (r. 96/715-99/717), while on hağğ, calls together a group of scholars to ask them about the acceptability of perfuming oneself before making the circumambulation of the Kaba called tawäf al-ifäda: they unanimously approve of it, with the exception of the caliph 'Umar's grandson, 'Abd Allāh b. 'Abd Allāh. ${ }^{121}$ In a similar report, the caliph al-Walīd b. 'Abd al-Malik asks the same question of two individuals: here, Hāriğa b. Zayd b. Tāabit allows the use of perfume, but another grandson of 'Umar's —Sālim b. 'Abd Allāh—forbids it. ${ }^{122}$ Several Umayyad-era jurists reportedly disliked any use of scent while in iḥrām: for example, Sa'ìd b. Ğubayr "found it detestable to anoint oneself with oil containing musk or aromatics while entering ị̂rām," and Ibrāhīm al-Naḩa'î, "if he saw a man who was

119 Wheeler, Mecca and Eden, p. 64-65; Thurlkill, Sacred Scents, p. 122-123.

120 On the prohibition, see: Maurice Gaudefroy-Demombynes, Le pélerinage à la Mekke: étude d'histoire religieuse, Paris, Paul Geuthner (“Annales du Musée Guimet," 33), 1923, p. 169, 186-191, 297; King, Scent from the Garden, p. 343-344.

121 Aḥmad b. Šu'ayb al-Nasā̄ì, al-Sunan al-kubrā, ed. Šu'ayb al-Arna'ūṭ and Ḥasan 'Abd al-Mu'nim Šalabī, Beirut, Mu’assasat al-risāla, 20o1, IV, p. 215-216 (nº 4146); Ibn Ḥazm, Muhallā, v, p. 71. In an alternate account, the scholars' disagreement leads Sulaymān to call upon the expertise of his father's (i.e. the caliph 'Abd al-Malik's) hairdresser to ask whether the previous caliph had used perfume: Ibn 'Asākir, Ta'rīh madinat Dimašq, LXIX, p. 96-97, 226-227. I thank Richard Heffron for drawing these versions to my attention. These reports parallel accounts of Sulaymān's asking jurists in the Hiğāz about 'Abd al-Malik's performance of the hağğ rites and his role in the construction of the Kacba: al-Ya'qūbī, Ta'rīh, II, p. 358; al-Azraqī, Ahbār Makka, p. 319-320 (nº 255). See discussion in: Hawting, "Hajj in the Second Civil War," p. 36-37; Robinson, Abd al-Malik, p. 94-95; McMillan, The Meaning of Mecca, p. 109; Reinhard Eisener, Zwischen Faktum und Fiktion: Eine Studie zum Umayyadenkalifen Sulaiman b. 'Abdalmalik und seinem Bild in den Quellen, Wiesbaden, Otto Harrassowitz, 1987, p. 192-193.

122 Mālik b. Anas, al-Muwatța' [recension of Abū Mușab al-Zuhrī l-Madanī], eds Baššār 'Awwād Ma'rūf and Mạ̣mūd Muḥammad Hualīl, Beirut, Mu’assasat al-risāla, 1998, I, p. 418 ( $\mathrm{n}^{\mathrm{o}}$ 1059); id., al-Muwatța' [recension of Suwayd b. Sa'ìd al-Ḥadatāān̄], ed. 'Abd al-Mağīd Turkī, Beirut, Dār al-g̉arb al-islāmī, 1994, p. 385 (nº 494); id., al-Muwațța' [recension of Yahyyā b. Yaḥyā l-Layțī l-Andalusī], ed. Baššār 'Awwād Ma'rūf, Beirut, Dār al-g̉arb al-islāmī, 1997, I, p. 443-444 (nº 924); id., al-Muwațta' [recension of 'Abd Allāh b. Maslama l-Qa'nabī], ed. 'Abd al-Mağìd Turkī, Beirut, Dār al-g̉arb al-islāmī, 1999, p. 369 (nº 58o). 
perfumed during ihrām, would order him to wash his head with dirt."123 Such ascetic attitudes appear to have been part of a "pious reaction against the practice, current in Umaiyad [sic] times," of wearing aromatics during the hağğ. ${ }^{124}$

Among those who reportedly approved of wearing aromatics while in ị̂ām are several Umayyads and Zubayrids, who, as we noted above, were instrumental in the institutionalization of the Ka'ba's perfuming. In addition to his appearance as one of the scholars who responded approvingly to Sulaymān b. 'Abd al-Malik's query about perfume, the Umayyad 'Umar b. 'Abd al-'Azīz reportedly was himself anointed with salīha (cassia bark) during ị̂ām.125 Among the Zubayrids, Ibn al-Zubayr was anointed with fine $\dot{g}$ ăliya during his ihrām, while his brother 'Urwa b. al-Zubayr fumigated his clothes with incense and perfumed himself with darira (a scented powder made with ingredients like musk and ambergris) and ben-tree oil. ${ }^{126}$ Thus, rather than depriving themselves of aromatics, some pilgrims - including figures from the dynasties in the middle of the political struggles over the scents at the Ka'ba and other sacred spaces - wore fine perfumes, made of materials understood to characterize the scents of paradise.

If these reports are an indication of patterns of behavior among early Muslims, we have further illustration of the place of aromatic scents at pilgrimage sites and in the recreation of paradise on earth at these locations. Not only were the pilgrimage spaces aromatized, but pilgrims themselves wore expensive perfumes. The redolent perfumes and incenses encountered at these spaces were almost certainly resonant with early Muslims' expectations of paradise, as described in the Qur'ān and other early Islamic sources. In his discussion of "the sensuousness and embodiment of sacred space," Julian Holloway notes that "the sanctity of space is corporeally enacted and physically sensed as sacred." ${ }^{127}$ Traversing perfumed spaces and surrounded by scented companions, visitors to these locations experienced "a ritual (pre-)enactment of the state of believers in the hereafter"128 where they could enjoy something of the

\footnotetext{
123 Ibn Abī Šayba, al-Mușannaf, v, p. 245-246 ( $\left.{ }^{\text {os }} 13666,13672\right)$.

124 Joseph Schacht, The Origins of Muhammadan Jurisprudence, Oxford, Clarendon Press, 1950, p. 155, citing the debates that appear in al-Šāfi'ì, al-Umm, III, p. 376-379 (n ${ }^{\text {os }}$ 10691078); X, p. 237-240 (n ${ }^{\text {os }} 273-281$ ).

125 Ibn Abī Šayba, al-Mușannaf, v, p. 242 ( $\mathrm{n}^{\circ}$ 13650). On salīha, see: Stephen G. Haw, "Cinnamon, Cassia, and Ancient Trade," Journal of Ancient History and Archaeology, 4/1 (2017), p. 5-18.

126 Ibn Abī Šayba, al-Mușannaf, v, p. 242-244 ( ${ }^{\text {os }}$ 13651-13654, 13661); Ibn Ḥazm, Muḥallā, v, p. 7o. On darîra, see: King, Scent from the Garden, p. 281.

127 Julian Holloway, "Make-Believe: Spiritual Practice, Embodiment, and Sacred Space," Environment and Planning A, 35 (2003), p. 1964-1965.

128 Lange, Paradise and Hell, p. 272.
} 
luxuries of paradise by "overwhelming the olfactory and visual senses." ${ }^{129}$ More than simply traveling to a sacred space, pilgrims would take in the divine presence of these locations through their bodies, including through their noses.

The sources studied here demonstrate that scent was an important component of early Islamic pilgrimage practices. Under the care of early caliphs and other officials, the Ka'ba, the Dome of the Rock, and other sites were filled and covered with incense and perfumes, as early authorities competed for the most elaborate olfactory patronage of these sacred sites. Early Muslims cherished not only the visual splendor of these spaces, but also the smell of them. Penetrating the pilgrimage sites themselves, these scents also followed pilgrims homeward, clinging to their clothes, and were carried away for usage in healing and blessing. Perhaps because of its ethereal and immaterial nature, scent was a piece of the sacred space that even some relatively restrictive early Islamic voices, such as Ibn Hanbal, thought could be acceptably transported away from sacred territory itself.

These smells likely contributed to the sense of community forged at (and through) these pilgrimage spaces. Historians of the senses suggest that scent plays a particularly strong role within the creation of shared experience during communal rites such as pilgrimage, the latter itself closely connected with the formation of communal identity. ${ }^{130}$ After the return home, scent enabled the connections, memories, and identities formed on pilgrimage to continue: the "memory of communion" could be "(re-)experienced through material culture,"131 such as the pilgrimage souvenirs that were often "intimately associated with the experience the pilgrims had received in the holy place."132 Indeed, discussing the relative fame of different late antique Christian saints'

129 Luke Treadwell, "The Formation of Religious and Caliphal Identity in the Umayyad Period: The Evidence of the Coinage," in Companion to Islamic Art and Architecture, ed. Flood and Necıpoğlu, I, p. 105.

130 Largey and Watson, "Sociology of Odors," p. 1031-1032; Howes, "Olfaction and Transition," p. 403-408; Constance Classen, "The Odor of the Other: Olfactory Symbolism and Cultural Categories," Ethos, 2o/2 (1992), p. 16o; Classen, Howes, and Synnott, Aroma, p. 140.

131 Eva Mol and Miguel John Versluys, "Material Culture and Imagined Communities in the Roman World," in A Companion to the Archaeology of Religion in the Ancient World, eds Rubina Raja and Jörg Rüpke, Malden, Wiley Blackwell ("Blackwell Companions to the Ancient World"), 2015, p. 456.

132 John Wilkinson, Jerusalem Pilgrims before the Crusades, Warminster, Aris \& Phillips, 2002, p. 72. 
cults throughout the Mediterranean world, Béatrice Caseau notes, "The scale and success of a cult depends in part on the existence of objects to be brought home."133 In this period when the sacred geography of Islam was still crystallizing, the aromas experienced and collected at sites such as the Dome of the Rock, the Ka'ba, and elsewhere perhaps functioned as a version of such "objects" that allowed the memories, fame, and sacrality of pilgrimage locations to reproduce and spread. Scented materials may have been particularly wellsuited to this task, given the strong physiological associations between the sense of smell and memories of past experiences. ${ }^{134}$

Scent could be called upon to identify pilgrims' identities to others: smelling, as one might, like "one of those who have entered the Șahra." Additionally, scent likely also assisted believers in conceptualizing their own experiences as pilgrims to Islamic sacred spaces. In an essay highlighting the importance of sensory experience to the "construction of meanings and narratives" of pilgrimage, Heather Hunter-Crawley writes:

How individuals move around a site, how they interact with each other and with their immediate environment, the sounds, sights, smells, and other sensations which they experience, all of these elements combine to constitute the memory and the meaning of a pilgrimage at the level of both individual and community. ${ }^{135}$

Writing about the experiences of pilgrims to the shrines of Saint Menas and Saint Symeon the Elder in late antique Egypt and Syria, Hunter-Crawley argues that the sensorial rituals carried out at these sites "materialized and reinforced the meanings of the individual cults," which in these two cases meant "the experience and meaning of these pilgrimages as a form of behavioural, sacred mimesis." ${ }^{136}$ The smells of fragrant oil and incense (re)produced pilgrims' experiences of these spaces and guided the meanings that they extracted from them.

To return to the beginning - the Dome of the Rock and its meaning for early Muslims - the sights, touches, and smells encountered there and at other early Islamic pilgrimage shrines likely evoked conceptions of paradise for early

\footnotetext{
133 Caseau, "Parfum et guérison," p. 188.

134 Howes, "Olfaction and Transition," p. 401-402; Trygg Engen, The Perception of Odors, New York, Academic Press, 1982, p. 97-112; id., Odor Sensation and Memory; Donald A. Wilson and Richard J. Stevenson, Learning to Smell: Olfactory Perception from Neurobiology to Behavior, Baltimore, Johns Hopkins University Press, 2006, p. 188-242.

135 Hunter-Crawley, "Movement as Sacred Mimesis," p. 189.

136 Ibid., p. 199.
} 
visitors. The Dome of the Rock's location on the Temple Mount, and the eschatological expectations connected with that space, undoubtedly factored into how the perfume and incense there were consumed and interpreted. ${ }^{137}$ However, rather than a uniquely Jewish or Christian practice connected exclusively with this specific space, such olfactory rituals were used by early Muslim worshippers at many early pilgrimage destinations. Paradisiacal and eschatological expectations and experiences characterized these early Islamic sacred spaces, with scent holding a prominent position at each of them. Due to the strongly olfactory conceptions of paradise present within early Islam, the walls covered in perfume and clouded with incense likely contributed to this sense of being within reach (or at least smell) of the hereafter. At these locations where the divine was believed to penetrate into the profane, smell offered an invisible but tangible manifestation of the sacredness of the location and an odorous glimpse of the future.

137 Tillier writes that "linterprétation eschatologique du H̦aram al-Sharif est largement ignorée des sources musulmanes postérieures [...] il semble que la signification originelle du dôme du Rocher ait été oubliée," but notes that non-eschatological paradisiacal themes continued to be present in later interpretations of the space: "Abd al-Malik, Muhammad et le Jugement dernier," p. 365. Scholars are divided regarding how long these rituals continued to be practiced at the Dome of the Rock; see, for example: Busse, "Temple of Jerusalem," p. 33; Amikam Elad, "Abd al-Malik and the Dome of the Rock: A Further Examination of the Muslim Sources," Jerusalem Studies in Arabic and Islam, 35 (2008), p. 181. Notably, al-Nuwayrī's Nihāyat al-arab reports that a type of nadd incensewhose recipe is ascribed to the mother of the 'Abbāsid caliph al-Muqtadir (r. 295/9o8320/932) — was used to "fumigate the Ka'ba and the Șahra of Jerusalem every Friday." The author of a book on scents, Muhammad b. Ahmad b. Sa'īd al-Tamīmī (d. after 370/980), is then quoted as saying that the "head of the servants in Jerusalem gave some of this nadd to my father," suggesting that the Dome still had servants producing perfume for it in the fourth/tenth century. Šihāb al-Dīn Aḥmad b. 'Abd al-Wahhāb al-Nuwayrī, Nihāyat al-arab fi funūn al-adab, eds Mufìd Qumayḥa et al., Beirut, Dār al-kutub al-ilmiyya, 2004, XII, p. 37. On this text, see: King, Scent from the Garden, p. 346; Zohar and Lev, "Trends in the Use," p. 26. 